Portland State University

PDXScholar

Post-Fire Changes in Interior Alaska's Vegetation Composition

Jannike E. Allen

Portland State University

Follow this and additional works at: https://pdxscholar.library.pdx.edu/honorstheses

Part of the Environmental Sciences Commons, and the Forest Sciences Commons Let us know how access to this document benefits you.

Recommended Citation

Allen, Jannike E., "Post-Fire Changes in Interior Alaska's Vegetation Composition" (2020). University Honors Theses. Paper 844.

https://doi.org/10.15760/honors.863

This Thesis is brought to you for free and open access. It has been accepted for inclusion in University Honors Theses by an authorized administrator of PDXScholar. Please contact us if we can make this document more accessible: pdxscholar@pdx.edu. 


\title{
Post-fire changes in interior Alaska's vegetation composition
}

\author{
by \\ Jannike Allen \\ An undergraduate honors thesis submitted in partial fulfillment of the \\ requirements for the degree of \\ Bachelor of Science \\ in \\ University Honors \\ and \\ Environmental Science
}

Thesis Adviser

Dr. Melissa Lucash

Portland State University 


\begin{abstract}
Global warming is altering the fire regime of interior Alaska, which may have cascading effects on the prevalence of forest types and species dominance across this region. Our objective was to investigate the relationship between vegetation composition and fire in the boreal forest of interior Alaska. We utilized data from over 700 plots sampled across the landscape designated as the Tanana region by the US Forest Service for Forest Inventory Analysis (FIA), as well as fire history records. We compared biomass and stem density of conifer and hardwood forest types, as well as individual tree species, across a gradient of landscape topography (uplands vs lowlands, aspect, slope, elevation), time since fire, and number of fires. Hardwood biomass was greater than conifer biomass and black spruce has far greater stem density than all other tree species. Conifer biomass was more affected by upland or lowland position and time since fire than elevation, slope (except at slopes $>25 \%$ ) or aspect. Conifer density was only affected by time since fire, increasing after 50 years. Hardwoods were more variable than conifers; biomass was only driven by time since fire and stem density was only driven by upland or lowland position. Several conifer and deciduous species (black spruce, balsam poplar, quaking aspen) showed a decline in biomass at sites that burned twice since 1940 compared to sites that burned once. White spruce and paper birch did not show a decline in biomass, and tamarack showed a decline in stem density. Certain elevation ranges, especially 1000-2050, were more favorable for high biomass levels of species such as white spruce and paper birch. Our results suggest that upland or lowland position and time since fire are more important variables than slope or aspect for determining forest type and species composition in this ecosystem, and that elevation is a variable that creates spaces on the landscape that may be favorable to a limited number of species. As fire increases in frequency and extent in Alaska, this may have important consequences for vegetation composition, thus creating lasting impacts on the landscape of Alaska for the foreseeable future.
\end{abstract}

\title{
Introduction
}

The boreal harbors vast amounts of carbon, the majority of which is stored belowground in soils (Bradshaw \& Warkentin, 2015). However, anthropogenic climate change is causing the rapid warming of high latitude regions. With more lightning strikes and drier fuels (Balshi et al., 2009; Flannigan et al., 2005), wildfire is increasing, and fire frequency is now higher than it has been in the past 3,000 years (Kelly et al., 2013). The boreal is the coldest, highest latitude forested biome (Chapin III et al., 2010) and is dominated primarily by conifers. With a changing fire regime, however, it is likely that species composition may shift to more deciduous species (Mekonnen et al., 2019) and carbon storage will be affected. Topographic conditions, including aspect, elevation, and slope, influence where tree species are able or likely to grow in the boreal forest and elsewhere. In interior Alaska, black spruce trees are mostly seen on north-facing aspects where conditions are cooler due to less insolation, and at high altitudes (Hollingsworth et al., 2006; Kurkowski et al., 2008). Hardwood tree species are common in warmer areas without permafrost (Kurkowski et al., 2008). Aspen stands are typically located where solar radiation is abundant, often on south slopes. Birch and white spruce often grow on moister and cooler sites than aspen, though they still require fairly high insolation levels, and are often found on east and west aspects; birch favors lower altitudes than aspen (Kurkowski et al., 2008). Balsam poplar also favor sites with moderate moisture (Harris, 1990). Slope can play a role in the local hydrology. Due to moisture accumulation in lowlands, especially when a thin active layer over 
permafrost prevents drainage (Johnstone, Chapin III, et al., 2010), lowlands are often dominated by conifers and are expected to burn less frequently than uplands. Fire is the primary disturbance in the boreal forest of Alaska and is the most common cause of tree mortality (Kurkowski et al., 2008). The fire regime in boreal Alaska historically consists of large infrequent fires. Interior Alaska's fire return interval is often considered to be roughly 100 years (Yarie, 1981). Black spruce stands show fire return intervals largely between 70-130 years (Johnstone, Hollingsworth, et al., 2010; Kasischke \& Johnstone, 2005). Short fire return intervals are considered to be less than 50 years, in this ecosystem (Brown \& Johnstone, 2012).

The boreal forests of Alaska are dominated by conifers. The most abundant conifer, black spruce, is adapted to fire disturbance, typically burns as crown fires, and produces semiserotinous cones that release seeds when fire occurs. Seedlings of serotinous species are established by seeds from nearby sources post fire (Brown \& Johnstone, 2012). Black spruce establishment is most successful within the first couple of decades after a mature black spruce forest burns, due to seed availability and adaptations to that state of seed bed. Mature black spruce forests have thick, moist organic layers along the forest floor, where Sphagnum moss is common. Permafrost below black spruce inhibits drainage, which contributes to the moisture retention (Johnstone, Chapin III, et al., 2010). When black spruce arrived in interior Alaska 5,000 years ago, there was an increase in fire on the landscape due to their flammability (Chapin, 2006). White spruce has different characteristics than black spruce, and is less resilient to fire, often having low success reestablishing post fire (Abrahamson, 2015). White spruce prefers well drained, warmer, permafrost free areas, and can be found in upland and riparian sites. Tamarack, a conifer that is less common in Alaska, can co-dominate with black spruce at moist sites with shallow permafrost, and occasionally is found in areas with white spruce or paper birch (Larix Laricina, n.d.). This species can reach ages of about 180 years, it disperses seed by wind in the fall, and has been noted to die following low intensity fires.

Although conifers dominate the boreal forests, hardwoods are quite prevalent throughout interior Alaska. Common hardwood species in Alaska include balsam poplar, paper birch, and quaking aspen. These hardwoods are resilient to fire and have adapted to resprout from roots and rhizomes in mineral soil or spread seeds using wind dispersal post fire. Mineral soil exposed by fire provides a seedbed for such colonizers (Johnstone, Chapin III, et al., 2010). Balsam poplar can produce seeds for wind dispersal eight years after germination, and expands its range using root suckers which also allow it to reestablish vigorously post fire (Harris, 1990). It requires a plentiful source of nutrients, especially calcium and magnesium. It is a pioneering species that can live up to 200 years, although if permafrost develops conditions may become more favorable to black spruce. Paper birch is a shorter-lived species, typically up to 140 years, and tends to reach a height of 20-60 feet (Uchytil, 1991). Birch seeds are dispersed by wind every other year after reaching maturity at 15 years. It is a pioneer species that is very successful on fire burned landscapes and will self-thin significantly 60-90 years after establishment. Birch are less flammable than black spruce, and their crowns are less likely to burn, which leaves trees to provide seeds post fire. Quaking aspen trees clone themselves along their root systems once they are a year old (Howard, 1996). Aspen is a shade intolerant species that eventually thins itself. Quaking aspen bark is not fire resistant, but stumps will vigorously resprout following such a disturbance, making use of its extensive root system.

The two most common successional pathways in the Alaskan boreal are self replacement, where the same species reestablishes after fire disturbance, and species dominance relay, where hardwoods dominate before conifers do, but seedlings of both establish early on (Kurkowski et 
al., 2008). Self replacement is common for stands of black spruce, aspen, and birch, especially in locations where the conditions are only favorable to one tree species. Species dominance relay can only occur when there is a long enough fire free interval at favorable locations, and this successional pathway is currently rare in the interior landscapes of Alaska (Kurkowski et al., 2008).

Although interior Alaska is considered a fire-dependent coniferous ecosystem, there is concern that conifer forests appear to be transitioning to hardwood dominance. Interior Alaska is experiencing an increase in area burned annually (Calef et al., 2015) and areas are reburning even when we might expect the fuel reduction of a first burn to prevent fire from occurring until after trees have matured. With shorter intervals between fires, a reburn can reduce seed availability and alter the substrate that seeds would germinate in (Brown \& Johnstone, 2012). Short interval fires at sites with black spruce dominance have been noted to have reduced seed availability and viability (Brown \& Johnstone, 2012). If a fire is too severe, the entire seed stock may be destroyed, and if the fire return interval is too short, the trees may die before reaching reproductive maturity and producing seeds (Brown \& Johnstone, 2012; Johnstone, Hollingsworth, et al., 2010). These sorts of changes mean that forests may not regrow as we would have expected them to in the past.

The goals of this study were to investigate how vegetation composition in the boreal forest of interior Alaska vary with the landscape's topography, time since fire, and number of fires. We present a summary of vegetation data sampled by the field crews of the US Forest Service Forest Inventory and Analysis (FIA) in 2014 and 2016, in combination with fire history data that began in 1940 .

\section{Methods}

\section{Study Area}

The study area is in interior Alaska's Tanana Valley, which is largely within Interior Highlands, Interior Bottomlands, and Interior Forested Lowlands \& Uplands (level 3 ecoregions, https://www.epa.gov/eco-research/level-iii-and-iv-ecoregions-state). In 2014, the US Forest Service established permanent plots for Forest Inventory Analysis (FIA) in the Tanana Valley, the first sample unit to have been established in the interior (Forest Inventory and Analysis Interior Alaska, 2018). The Tanana Valley is owned by the state of Alaska and includes several forest types: black spruce, white spruce, aspen, birch, and poplar, with black spruce covering nearly half of the land cover (Forest Inventory and Analysis - Interior Alaska, 2018). This region exhibits relatively low species diversity but a variety of landscape types. Floodplains, permafrost-free upland forests, and permafrost-dominated uplands and lowlands each create conditions that favor certain successional trends, which are diversified further by disturbance regimes (Chapin, 2006).

\section{$\underline{\text { Data Collection }}$}

Forest Inventory Analysis

Field data was collected in the Tanana region by the US Forest Service's Forest Inventory Analysis (FIA) program, which extended into interior Alaska starting in 2014. In 2014 and 2016, 774 permanent plots were established and measured with sufficient location data to relate them to other datasets. FIA plots were sampled for trees with diameter at breast height (dbh) of $12.7 \mathrm{~cm}$ or greater within four subplots that have fixed radii of $7.32 \mathrm{~m}$. One subplot is around 
the center point of the plot; the other three are positioned around points $36.58 \mathrm{~m}$ from the center point, at 0, 120, and 240 degree azimuths (Patton et al., 2018). Aboveground carbon in each tree $\geq 1.0$ inch diameter at breast height ( $\mathrm{dbh}$ ) and diameter at root collar (drc) is calculated for trees, excluding their foliage. Trees per acre for each plot are recorded based on stem counts within subplots. Biomass and stem counts were used with expansion factors dependent on the plot area to calculate biomass and stem density on an area basis.

\section{Fire Data}

Maps of time since fire and number of fires were derived from the Alaska Large Fires Database (Alaska Fire History Perimeter Polygons, 2019), which has records of fire perimeters beginning in 1940. This dataset is comprehensive, though the amount of detail recorded increased over time; prior to 1987, only fire perimeters of at least 1000 acres were mapped, from 1987-2015, perimeters of at least 100 acres were mapped, and since 2016, fires over 10 acres were mapped. The spatialEco package in R (Evans, 2018) was used to extract associated fire years from this dataset for FIA plot locations.

\section{Topographic and Vegetation Data}

Two arc-second digital elevation models of Alaska were downloaded from USGS (U.S. Geological Survey, 2017), and percent slope, aspect, and elevation were derived from this using the terrain function from the raster package in R (Hijmans, 2019). The Alaska Vegetation and Wetland Composite map was downloaded from the Alaska Center for Conservation Science (Alaska Vegetation and Wetland Composite, 2017) to distinguish between uplands and wetlands. Data on elevation, slope, aspect, coarse landcover type and presence of wetlands were extracted for each FIA plot location using the raster package in R (Hijmans, 2019).

$\underline{\text { Analysis }}$

RStudio software was used to analyze the FIA plot data, using biomass and stem density as indicators of the effects of time since fire, number of reburns, aspect, land type, slope, and elevation. NA values for each particular variable were removed for graphs depicting that variable. Time since fire was restricted to 0-75 years, excluding plots with unknown values. Black cottonwood was removed since it was present in only one FIA plot.

\section{Results}

\section{Overview of FIA plots}

The majority of FIA plots are located on flat slopes (0-5\%) (Figure 2). Uplands are the dominant land type, and wetlands only occur at flatter slopes where water can pool. Vegetation cover on north-facing slopes (NW, N, NE) have more conifer dominating species composition than southfacing slopes (SW, S, SE) (Figure 3). South-facing slopes have more deciduous dominance and shrub/ herbaceous dominance than north-facing slopes. The majority of plots were in uplands $(n=667)$, with fewer plots located in wetlands $(n=97)$ (Figure 4, Figure 5). The plots were distributed across a wide range of elevation, with at least 80 plots in each 500 feet bin up to 3000 feet (Figure 6).

Once plots missing key variables were removed, the majority of the remaining 764 FIA plots were not burned $(n=459)$ in the time since 1940, however 269 burned once and 36 burned twice (Figure 7). Most of the FIA plots that burned within the 75 years prior to sampling fell 
into a 0-25 time since fire category $(\mathrm{n}=213)$, however 49 were sampled $26-50$ years since fire, and 38 were sampled 51-75 years since fire (Figure 8). Most of the plots were in uplands, having burned only once in recorded history (Figure 5).

\section{Topography controls on biomass and stem density}

Hardwoods overall had higher biomass $\left(\mathrm{g} \mathrm{m}^{-2}\right)$ than conifers, while conifers had much higher stem densities (\# stems per ha) than hardwoods (Figure 9). Hardwood species (balsam poplar, paper birch, and quaking aspen) have higher biomass than most conifers, although white spruce was comparable (Figure 10A). Black spruce had a significantly higher stem density than all other tree species (Figure 10B).

Conifer biomass was clearly lower in wetlands than in uplands (Figure 11 A). Both black and white spruce had lower biomass in the lowlands (Figure 12A). Hardwood biomass was so variable, particularly in the wetlands, that it was not different between uplands and wetlands (Figure 11A). Stem density of conifers was similar in uplands and lowlands, driven by high stem density of black spruce (Figure 12B). Hardwood stem density was higher in the uplands than wetlands, driven by paper birch and quaking aspen (Figure 11A, Figure 12A).

Hardwood biomass was greater than conifer biomass at most elevations, except at the highest elevations when conifers dominated (2500-3500 feet, Figure 13A). For both conifers and hardwoods, biomass appeared greatest at mid elevations, which is strongly reflected by white spruce and paper birch, but not by black spruce which doesn't have a strong link to elevation (Figure 14A). There was higher conifer stem density than hardwood density at every elevation, however, stem density declines as elevation increases for both forest types (Figure 13B).

Conifer stem density decreased with steepening of slopes and had the most biomass on 11-15\% slopes with high levels of black spruce and white spruce (Figure 15, Figure 16A). Hardwood stem densities were fairly consistent on all slopes flatter than $26 \%$, which primarily reflects the preference for flatness of paper birch and quaking aspen, but exhibited a large amount of variation at $26-30 \%$ slope plots due to paper birch's variability. Hardwood biomass was highest at 11-20\% slope plots due to paper birch.

Surprisingly, there was not a distinguishable difference in biomass or stem counts between north facing plots and south facing plots when compared (Figure 17). However, tamarack stem density was higher on north aspects than south aspects (Figure 18B).

\section{Effects of fire on forest type and species composition}

When comparing the percentage of plots burned or unburned in wetlands and non-wetlands, they show similar distributions (Figure 19). Approximately $60 \%$ of wetland plots and $60 \%$ of nonwetland plots were unburned. $33 \%$ of wetland plots and $36 \%$ of non-wetland plots were burned once. $7 \%$ of wetland plots and $4 \%$ of non-wetland plots were burned twice.

Hardwoods grew much faster than conifers and are seen to have significantly higher biomass within 75 years (Figure 20A). Balsam poplar biomass peaked in 26-50 years, and then declined over time. Conifers, driven by black spruce, filled in with higher stem density than hardwoods (Figure 20B). Meanwhile, white spruce stem density did not change significantly (Figure 21B). Hardwood stem density was relatively flat over time, however paper birch and balsam poplar appeared to thin themselves somewhat.

Conifer biomass and stem density were relatively consistent whether the plots they were located at have burned once or twice within the fire record time frame (Figure 22). However, black spruce biomass was seen to decline slightly with increased number of fires (Figure 
23A). White spruce biomass did not seem affected by an increase in burns. Hardwood biomass and stem density were relatively consistent across number of fires, however quaking aspen biomass decreased and balsam poplar was not present at twice burned sites. Tamarack slightly decreased in stem density with an increase in burns (Figure 23B). Biomass and stem density for both conifers and hardwoods were variable at twice burned sites.

\section{Discussion}

Carbon storage in boreal forests is significant on a global level (Bradshaw \& Warkentin, 2015) and research in Alaska can help investigate how this important ecosystem is operating. The Bonanza Creek Long Term Ecological Research site (LTER) has provided a venue for much of the existing Alaska boreal research, however it includes only about 32 plots, while the FIA Tanana region includes over seven hundred plots (Bonanza Creek LTER, n.d.). With the establishment of permanent plots by the US Forest Service's FIA program, 2014 marks the start of interior Alaska's most extensive sampling effort to date ("Forest Inventory and Analysis Interior Alaska"). FIA plots are positioned on a large range of slope, aspect, and elevation. The majority of plots are on upland sites and varied vegetation types are included. Tree vegetation metrics are just one small portion of the data gathered at FIA plots, making it a valuable resource to investigate countless research questions and be able to further observe and analyze changes in interior Alaska going forward.

FIA did not select sites with a focus on representing a stratification of fire histories, of those with known time since fire, the majority burned $0-25$ years prior to sampling. This lack of stratification also led to more plots located in uplands than lowlands. Fire perimeters were recorded starting in 1940, so with this time frame in mind we recognize that a zero burn value doesn't mean the site has never burned, but signifies an unknown time since fire, seventy-seven years or greater.

We noticed a much faster growing trend in hardwoods than conifers, and given that carbon is approximately half the weight of biomass, this indicates greater carbon storage within hardwood trees than conifers (Figure 20A). A study using airborne data collection along flight lines found that in boreal Alaska, mean aboveground biomass of hardwoods was $87.4 \mathrm{Mg} / \mathrm{ha}$, and for conifers it was $56.3 \mathrm{Mg} / \mathrm{ha}$ (Margolis et al., 2015). However, this doesn't necessarily mean that a shift to more hardwood dominance would lead to a net increase in carbon storage. Hardwood colonization of areas that previously were black spruce forests can coincide with alteration of soil conditions due to severe fires (Johnstone, Hollingsworth, et al., 2010; Kasischke $\&$ Johnstone, 2005). Removal of insulating moss and overstory shade are two factors that promote melting of permafrost (Viereck \& Schandelmeier, 1980). Increased active layer thickness and reduced permafrost can allow previously frozen carbon to decompose (Fisher et al., 2016). A comparison of black spruce and Alaska paper birch in the Tanana Valley State Forest roughly 70 years following the Murphy Dome Fire, found that although birch, a hardwood species, had higher above ground carbon, $78 \%$ of carbon associated with black spruce was stored in the soil, and when taking into account carbon stocks in aboveground, soil organic layer, and $10 \mathrm{~cm}$ of mineral soil, the two species exhibited comparable carbon storage (Melvin et al., 2015).

Stem density has shown itself to be a differentiating trait. Black spruce is unique from other tree species in interior Alaska, given its exceptionally high stem densities (Figure 10). In a previous study site with time since fire of 70 years, black spruce were found to have over seven 
times the stem densities of Alaska paper birch (Melvin et al., 2015). Hardwoods in the Tanana region plots did not have as high stem densities as black spruce, a pattern that becomes more apparent as time increases, since hardwoods have demonstrated self-thinning, thereby reducing their stem densities over time.

Although white spruce is quite similar in physical appearance to black spruce, these species were quite different in their responses to fire and topography. White spruce biomass was more comparable to that of hardwoods, especially paper birch, than black spruce (Figure 10). This reinforces how inaccurate it would be to lump the two spruce species of the region together. Past studies have viewed white spruce as a climax species in some sites, while at other sites they have the potential to give way to black spruce dominance if wet, cold, permafrost conditions develop (Viereck \& Schandelmeier, 1980). White spruce stands have also been noted to remain unburned even while black spruce stands burn beside them, indicating the potential for differences in likelihood of burning (Quirk \& Sykes, 1971).

Our data suggests that wetlands and uplands are equally likely to burn (Figure 19). This finding is surprising and could either indicate that these locations are burning at the same rate, or that the vegetation map we used to separate them is not accurate enough to distinguish between landscape position. There was also roughly six times as many plots in uplands compared to wetlands, making the sample distribution less than ideal for comparative analysis. If they are burning at the same rate, this may be occurring since black spruce grow well in moist conditions yet are more flammable than hardwoods (Chapin, 2006), perhaps counteracting the fire retardant properties of moisture. This has repercussions for fire managers who assume that lowlands do not burn as frequently as uplands. Alarmingly, our results suggest that the assumptions managers make about what sorts of vegetated areas can be used as fire breaks may not be as reliable as they were in the past, which may hamper the success of firefighting efforts.

The discourse on succession in boreal Alaska has long depicted hardwood dominance giving way to conifer dominance. While this relay succession's likelihood of occurrence depends on site specific conditions (Kurkowski et al., 2008), upland white spruce sites have been characterized as reaching a dense hardwood stage 26-50 years post fire, a mature hardwood stage 51-100 years post fire, and a mixed white spruce/ hardwood stage after 100 years post fire (Viereck \& Schandelmeier, 1980). This trend may be reflected in our data by the slight decrease in hardwood stem density 26-50 years post fire from plots across all topographies (Figure 20B). Our data also reinforces the faster growth rate of hardwoods compared to conifers.

In other ecosystem types, reburns have been observed to cause extreme shifts in vegetation composition (Zedler et al., 1983). A study of boreal forest in the Yukon Territory of Canada noted black spruce's susceptibility to short interval reburns, since they need enough time to mature for seed production to occur, without which they would be unable to recolonize post fire (Brown \& Johnstone, 2012). Black spruce are otherwise considered to be a fire resilient species, given their semi-serotious cone adaptations that disperse large quantities of seeds postfire (Greene \& Johnson, 1999). We expected to see a larger decline in black spruce at twice burned sites compared to once burned sites than we did (Figure 23). This may indicate that the resilience of black spruce to fire is greater at the landscape scale across a range of severities and topographic variables. However, it is still worth monitoring for greater reductions in black spruce that are likely in the future as viable seeds may become less abundant. Several hardwood species, particularly aspen and poplar, displayed a decrease in biomass with increase in times burned (Figure 23A). This adds support for changes being likely in a future of increased reburns, perhaps even creating conditions that allow for increased graminoid dominance. 
FIA data enabled this study to occur, but the use of existing data not explicitly designed for this study inherently includes some limitations. The plot locations were not stratified to equally represent varied fire histories or topographic variables. It was also not possible to determine what vegetation composition was present before fire occurred, limiting the implications of this study. For example, most studies looking at reburns are careful to select black spruce dominated sites that reburned, but we were unable to ascertain the species composition prior to our reburns.

Our results suggest that upland or lowland position and time since fire are more important variables than slope or aspect for determining forest type and species composition in this ecosystem, and that elevation is a variable that creates spaces on the landscape that may be favorable to a limited number of species. Our results also suggest that the projected shift from conifer to deciduous dominance with greater fire frequency under climate change may cause aboveground biomass to increase, but tree density to decline. As fire increases in frequency and extent in Alaska, this may have important consequences for vegetation composition, thus creating lasting impacts on the landscape of Alaska for the foreseeable future.

\section{Acknowledgements}

Thanks to Dr. Andrew Gray at the Forest Service for early access to FIA data. Thanks also to Dr. Melissa Lucash for advising, guidance, and editing, Shelby Weiss for data assistance, describing methods for obtaining data, and support, Katherine Hayes for ideas and input, Pauline Allen for assistance on this manuscript, and Max Blust and Dena Allen for helping keep me fed.

\section{References}

Abrahamson, I. (2015). Picea glauca, white spruce. In: Fire Effects Information System, [Online]. U.S. Department of Agriculture, Forest Service, Rocky Mountain Research Station, Fire Sciences Laboratory (Producer). Available: https://www.fs.fed.us /database/feis/plants/tree/picgla/all.html [2020, May 3].

Alaska Fire History Perimeter Polygons. (2019). Alaska Wildland Fire Coordinating Group (AWFCG) and Alaska Interagency Coordination Center (AICC). https://fire.ak.blm.gov/predsvcs/maps.php From the Alaska Fire History Perimeter Polygons metadata abstract: For wildfires occurring before 1987, emphasis was placed on mapping perimeters of at least 1,000 acres. From 1987 to 2015, emphasis was placed on mapping wildfires with perimeters of at least 100 acres. From 2016 forward, fires over 10 acres should be associated with perimeters. The delineations range in quality from hand sketched perimeters drawn on topographic maps to heads-up interpretation of fine scale satellite imagery (e.g., Sentinel2 imagery, 10 meter resolution). Although this is a comprehensive dataset, it is not complete and is subject to revision.

Alaska Vegetation and Wetland Composite. (2017). Alaska Center for Conservation Science. https://accscatalog.uaa.alaska.edu/dataset/alaska-vegetation-and-wetland-composite

Balshi, M. S., McGuirez, A. D., Duffy, P., Flannigan, M., Walsh, J., \& Melillo, J. (2009). Assessing the response of area burned to changing climate in western boreal North America using a Multivariate Adaptive Regression Splines (MARS) approach. Global Change Biology, 15(3), 578-600. https://doi.org/10.1111/j.1365-2486.2008.01679.x 
Bonanza Creek LTER. (n.d.). Retrieved May 14, 2020, from

http://www.lter.uaf.edu/research/study-sites-bcef

Bradshaw, C. J. A., \& Warkentin, I. G. (2015). Global estimates of boreal forest carbon stocks and flux. Global and Planetary Change, 128, 24-30. https://doi.org/10.1016/j.gloplacha.2015.02.004

Brown, C. D., \& Johnstone, J. F. (2012). Once burned, twice shy: Repeat fires reduce seed availability and alter substrate constraints on Picea mariana regeneration. Forest Ecology and Management, 266, 34-41. https://doi.org/10.1016/j.foreco.2011.11.006

Calef, M. P., Varvak, A., McGuire, A. D., Chapin, F. S., \& Reinhold, K. B. (2015). Recent Changes in Annual Area Burned in Interior Alaska: The Impact of Fire Management. Earth Interactions, 19(5), 1-17. https://doi.org/10.1175/EI-D-14-0025.1

Chapin, F. S. (2006). Alaska's changing boreal forest. Oxford University Press.

Chapin III, F. S., McGuire, A. D., Ruess, R. W., Hollingsworth, T. N., Mack, M. C., Johnstone, J. F., Kasischke, E. S., Euskirchen, E. S., Jones, J. B., Jorgenson, M. T., Kielland, K., Kofinas, G. P., Turetsky, M. R., Yarie, J., Lloyd, A. H., \& Taylor, D. L. (2010). Resilience of Alaska's boreal forest to climatic change. Canadian Journal of Forest Research, 40(7), 1360-1370. https://doi.org/10.1139/X10-074

Evans, J. (2018). R package version 0.1.1-1._spatialEco_. https://CRAN.Rproject.org/package $=$ spatialEco

Fisher, J. P., Estop-Aragonés, C., Thierry, A., Charman, D. J., Wolfe, S. A., Hartley, I. P., Murton, J. B., Williams, M., \& Phoenix, G. K. (2016). The influence of vegetation and soil characteristics on active-layer thickness of permafrost soils in boreal forest. Global Change Biology, 22(9), 3127-3140. https://doi.org/10.1111/gcb.13248

Flannigan, M. D., Logan, K. A., Amiro, B. D., Skinner, W. R., \& Stocks, B. J. (2005). Future area burned in Canada. Climatic Change, 72(1-2), 1-16. https://doi.org/10.1007/s10584005-5935-y

Forest Inventory and Analysis - Interior Alaska. (2018, February 21). Biomass-and-Carbon | PNW Research Station, USDA Forest Service. https://www.fs.fed.us/pnw/rma/maintopics/interior-Alaska/index.php. https://www.fs.fed.us/pnw/rma/localresources/documents/TananaHighlights2-8-18.pdf

Greene, D. F., \& Johnson, E. A. (1999). Modelling recruitment of Populus tremuloides, Pinus banksiana, and Picea mariana following fire in the mixedwood boreal forest. 29, 12.

Harris, H. (1990). Populus balsamifera subsp. Balsamifera. In: Fire Effects Information System, [Online]. U.S. Department of Agriculture, Forest Service, Rocky Mountain Research Station, Fire Sciences Laboratory (Producer). Available: https://www.fs.fed.us/database/feis/plants/tree/plaocc/all.html

Hijmans, R. J. (2019). R package version 2.8-19. Raster: Geographic Data Analysis and Modeling. https://CRAN.R-project.org/package=raster

Hollingsworth, T. N., Walker, M. D., Chapin III, F. S., \& Parsons, A. L. (2006). Scale-dependent environmental controls over species composition in Alaskan black spruce communities. Canadian Journal of Forest Research, 36(7), 1781-1796. https://doi.org/10.1139/x06061

Howard, J. (1996). Populus tremuloides. In: Fire Effects Information System, [Online]. U.S. Department of Agriculture, Forest Service, Rocky Mountain Research Station, Fire Sciences Laboratory (Producer). Available: https://www.fs.fed.us/database/feis/plants/tree/poptre/all.html 
Johnstone, J. F., Chapin III, F. S., Hollingsworth, T. N., Mack, M. C., Romanovsky, V., \& Turetsky, M. (2010). Fire, climate change, and forest resilience in interior Alaska. Canadian Journal of Forest Research, 40(7), 1302-1312. https://doi.org/10.1139/X10061

Johnstone, J. F., Hollingsworth, T. N., Chapin, F. S., \& Mack, M. C. (2010). Changes in fire regime break the legacy lock on successional trajectories in Alaskan boreal forest. Global Change Biology, 16(4), 1281-1295. https://doi.org/10.1111/j.1365-2486.2009.02051.x

Kasischke, E. S., \& Johnstone, J. F. (2005). Variation in postfire organic layer thickness in a black spruce forest complex in interior Alaska and its effects on soil temperature and moisture. Canadian Journal of Forest Research, 35(9), 2164-2177. https://doi.org/10.1139/X05-159

Kelly, R., Chipman, M. L., Higuera, P. E., Stefanova, I., Brubaker, L. B., \& Hu, F. S. (2013). Recent burning of boreal forests exceeds fire regime limits of the past 10,000 years. Proceedings of the National Academy of Sciences, 110(32), 13055-13060. https://doi.org/10.1073/pnas.1305069110

Kurkowski, T. A., Mann, D. H., Rupp, T. S., \& Verbyla, D. L. (2008). Relative importance of different secondary successional pathways in an Alaskan boreal forest. Canadian Journal of Forest Research, 38(7), 1911-1923. https://doi.org/10.1139/X08-039

Larix laricina. (n.d.). Fire Effects Information System (FEIS). Retrieved May 15, 2020, from https://www.fs.fed.us/database/feis/plants/tree/larlar/all.html\#DISTRIBUTION\%20AND $\% 200 C C U R R E N C E$

Margolis, H. A., Nelson, R. F., Montesano, P. M., Beaudoin, A., Sun, G., Andersen, H.-E., \& Wulder, M. A. (2015). Combining satellite lidar, airborne lidar, and ground plots to estimate the amount and distribution of aboveground biomass in the boreal forest of North America. Canadian Journal of Forest Research, 45(7), 838-855. https://doi.org/10.1139/cjfr-2015-0006

Mekonnen, Z. A., Riley, W. J., Randerson, J. T., Grant, R. F., \& Rogers, B. M. (2019). Expansion of high-latitude deciduous forests driven by interactions between climate warming and fire. Nature Plants, 5(9), 952-958. https://doi.org/10.1038/s41477-0190495-8

Melvin, A. M., Mack, M. C., Johnstone, J. F., David McGuire, A., Genet, H., \& Schuur, E. A. G. (2015). Differences in Ecosystem Carbon Distribution and Nutrient Cycling Linked to Forest Tree Species Composition in a Mid-Successional Boreal Forest. Ecosystems, 18(8), 1472-1488. https://doi.org/10.1007/s10021-015-9912-7

Patton, S. R., Russell, M. B., Windmuller-Campione, M. A., \& Frelich, L. E. (2018). Quantifying impacts of white-tailed deer (Odocoileus virginianus Zimmerman) browse using forest inventory and socio-environmental datasets. PLOS ONE, 13(8), e0201334. https://doi.org/10.1371/journal.pone.0201334

Quirk, W. A., \& Sykes, D. J. (1971). White spruce stringers in a fire-patterned landscape in interior Alaska. Fire in the Northern Environment, 179-197.

Uchytil, R. J. (1991). Betula papyrifera. In: Fire Effects Information System, [Online]. U.S. Department of Agriculture, Forest Service, Rocky Mountain Research Station, Fire Sciences Laboratory (Producer). Available: https://www.fs.fed.us/database/feis/plants/tree/betpap/all.html

U.S. Geological Survey. (2017). Alaska 2 Arc-second Digital Elevation Models (DEMs)—USGS National Map 3DEP Downloadable Data Collection. 
https://catalog.data.gov/dataset/national-elevation-dataset-ned-alaska-2-arc-seconddownloadable-data-collection-national-geosp

Viereck, L. A., \& Schandelmeier, L. A. (1980). Effects of Fire in Alaska and Adjacent Canada: A Literature Review. 132.

Yarie, J. (1981). Forest Fire Cycles and Life-Tables-A Case-Study from Interior Alaska. Canadian Journal of Forest Research-Revue Canadienne De Recherche Forestiere, 11(3), 554-562. https://doi.org/10.1139/x81-076

Zedler, P. H., Gautier, C. R., \& McMaster, G. S. (1983). Vegetation change in response to extreme events: The effect of a short interval between fires in California chaparral and coastal scrub. Ecology, 64(4), 809-818. 


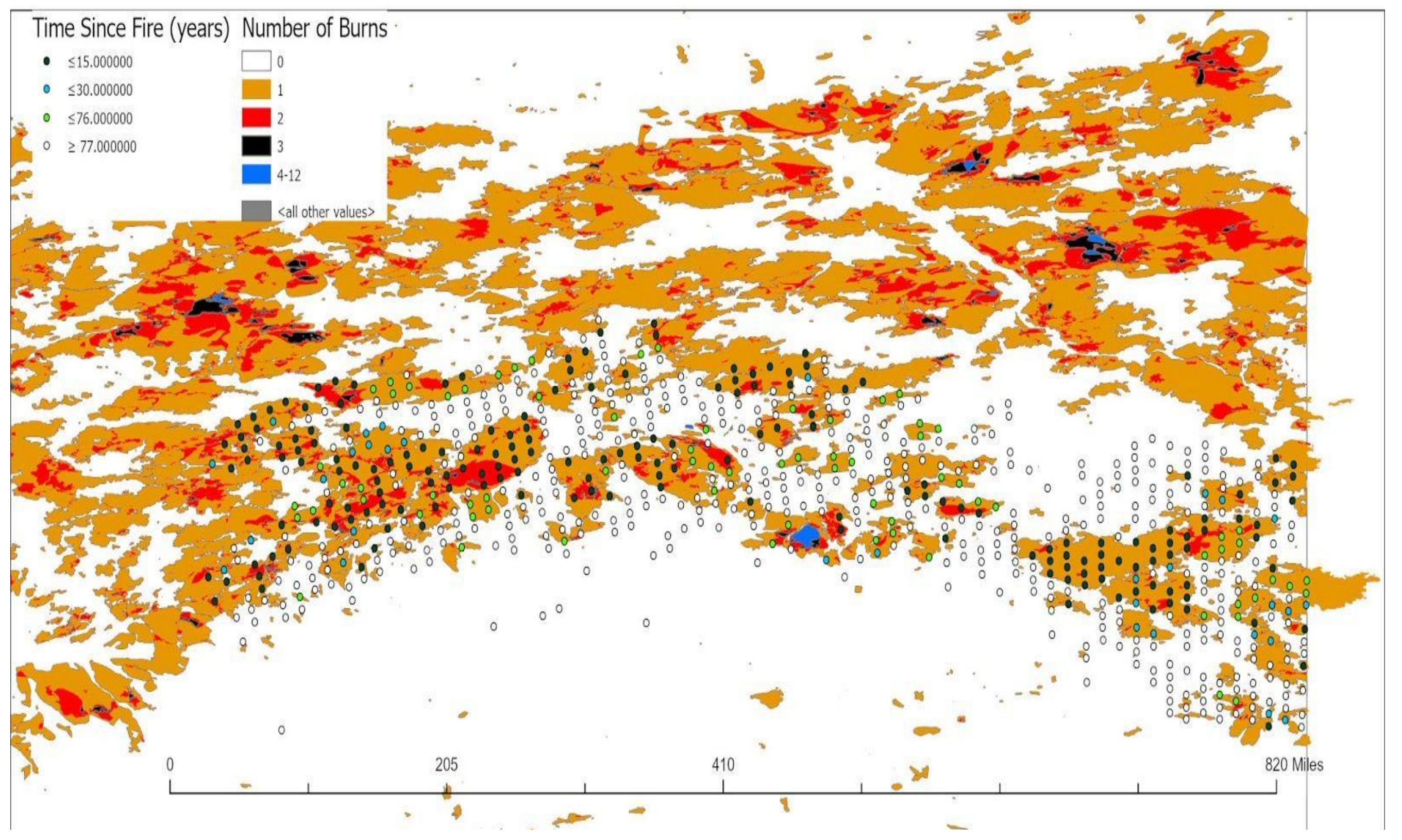

Figure 1. Map of Tanana FIA plots in relation to fire history. . 


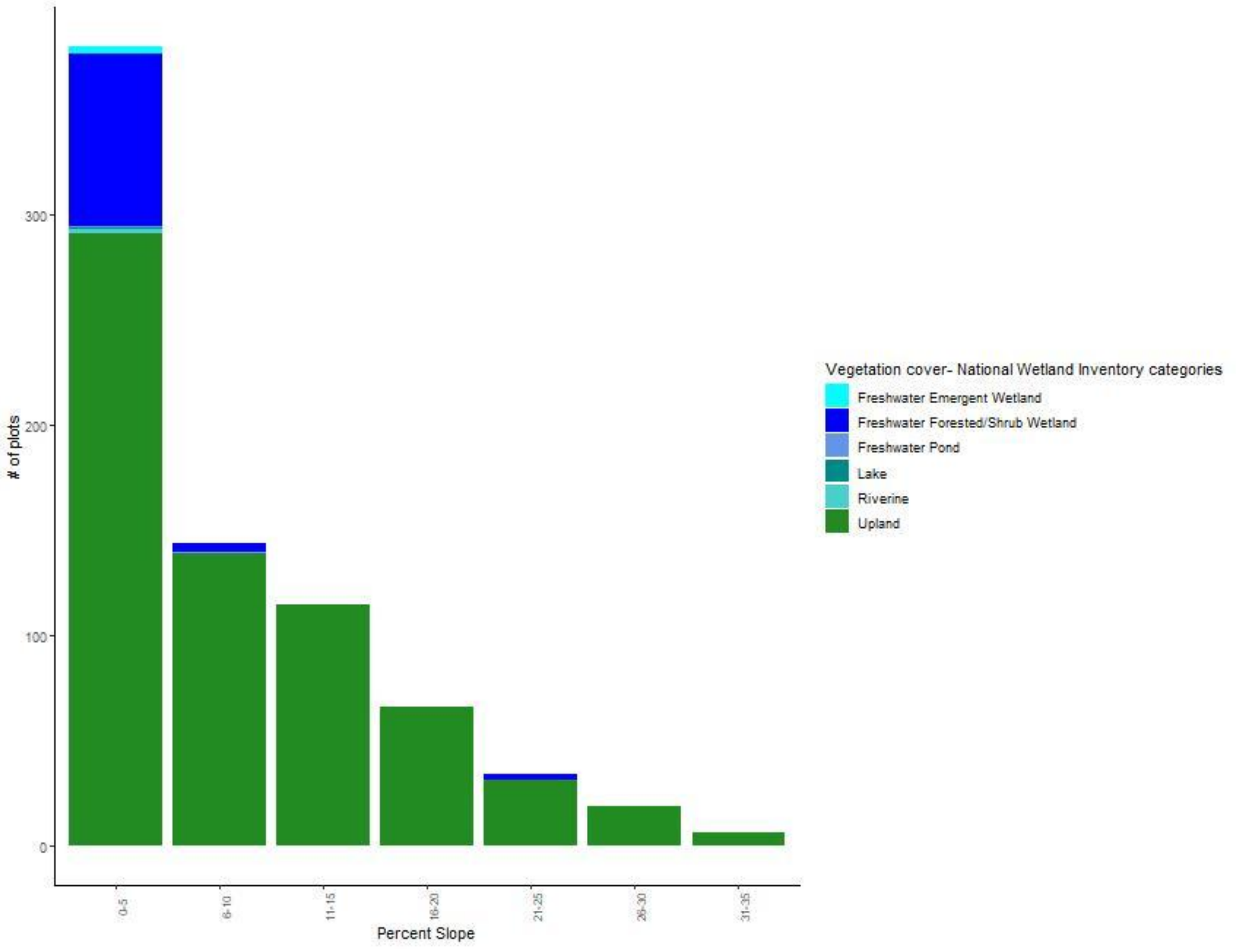

Figure 2. Histogram of plot counts with slope and vegetation types. 


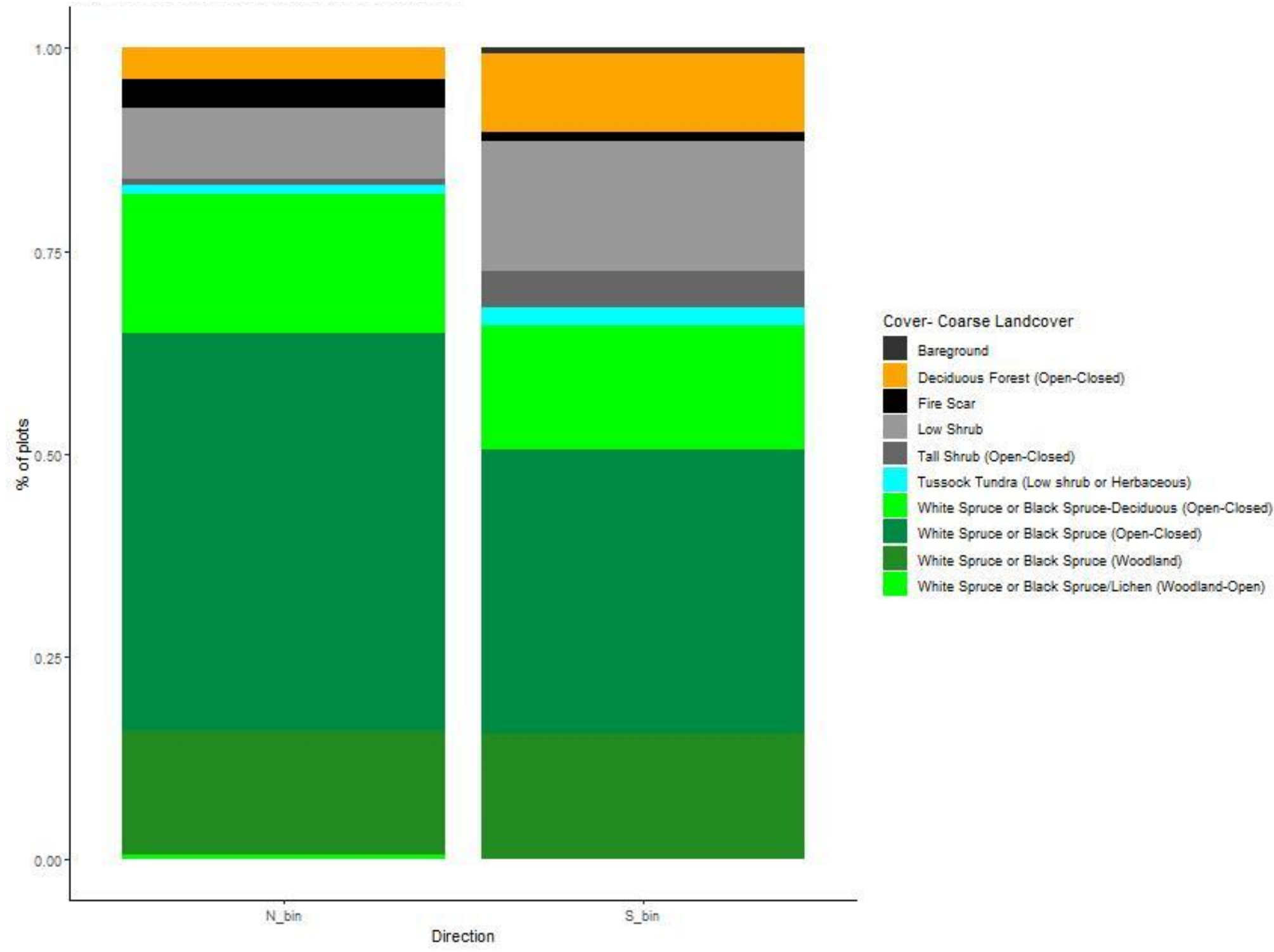

Figure 3. Vegetation types of FIA plots on N_bin aspects (NE, N. NW) and S_bin aspects (SE, S, SW). 


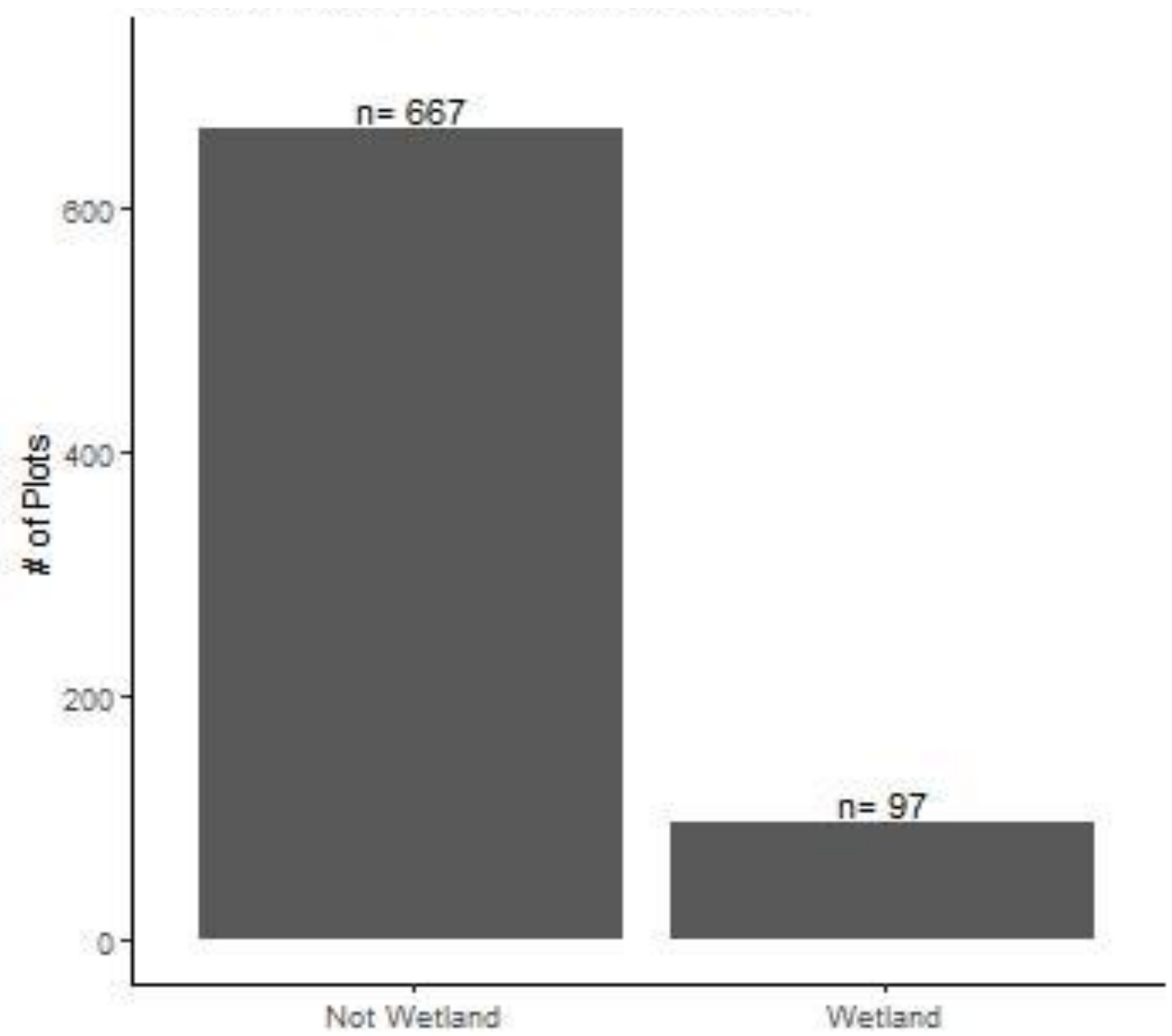

Figure 4. Histogram of plot counts with wetlands and non-wetlands. 


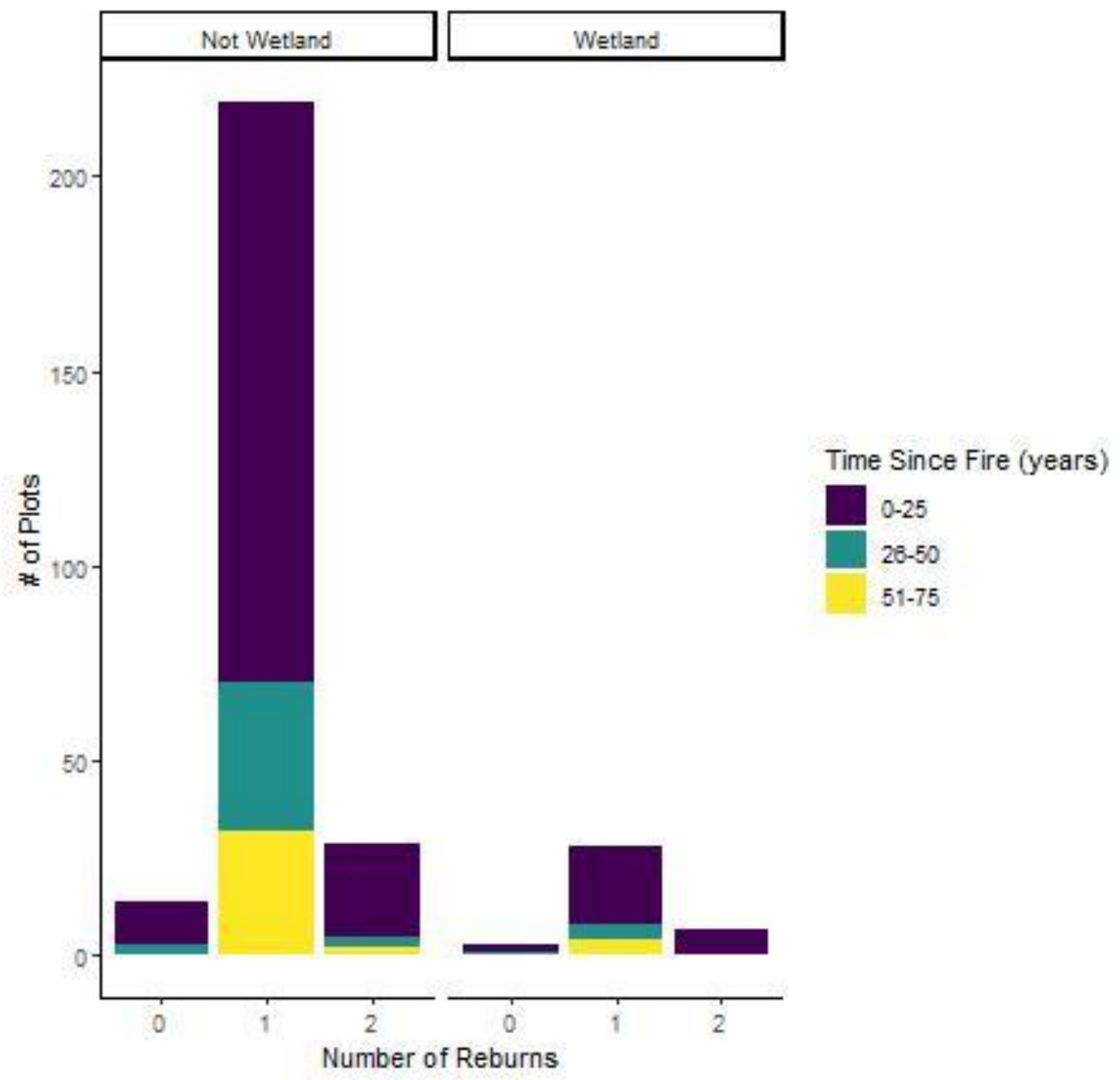

Figure 5. Histogram of plot counts with time since fire and number of reburns for wetlands and non-wetlands. 


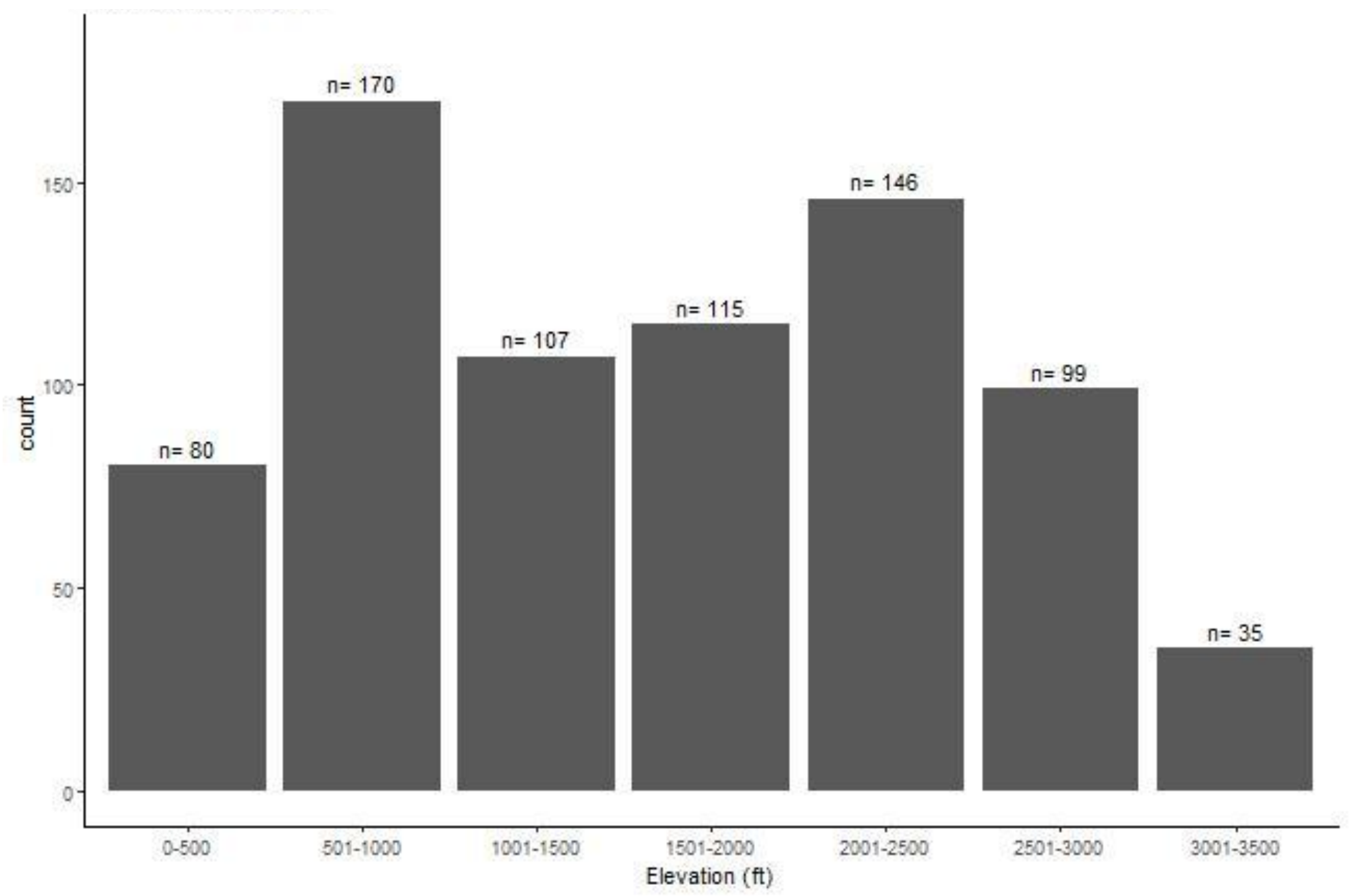

Figure 6. Histogram of plot counts with elevation. 


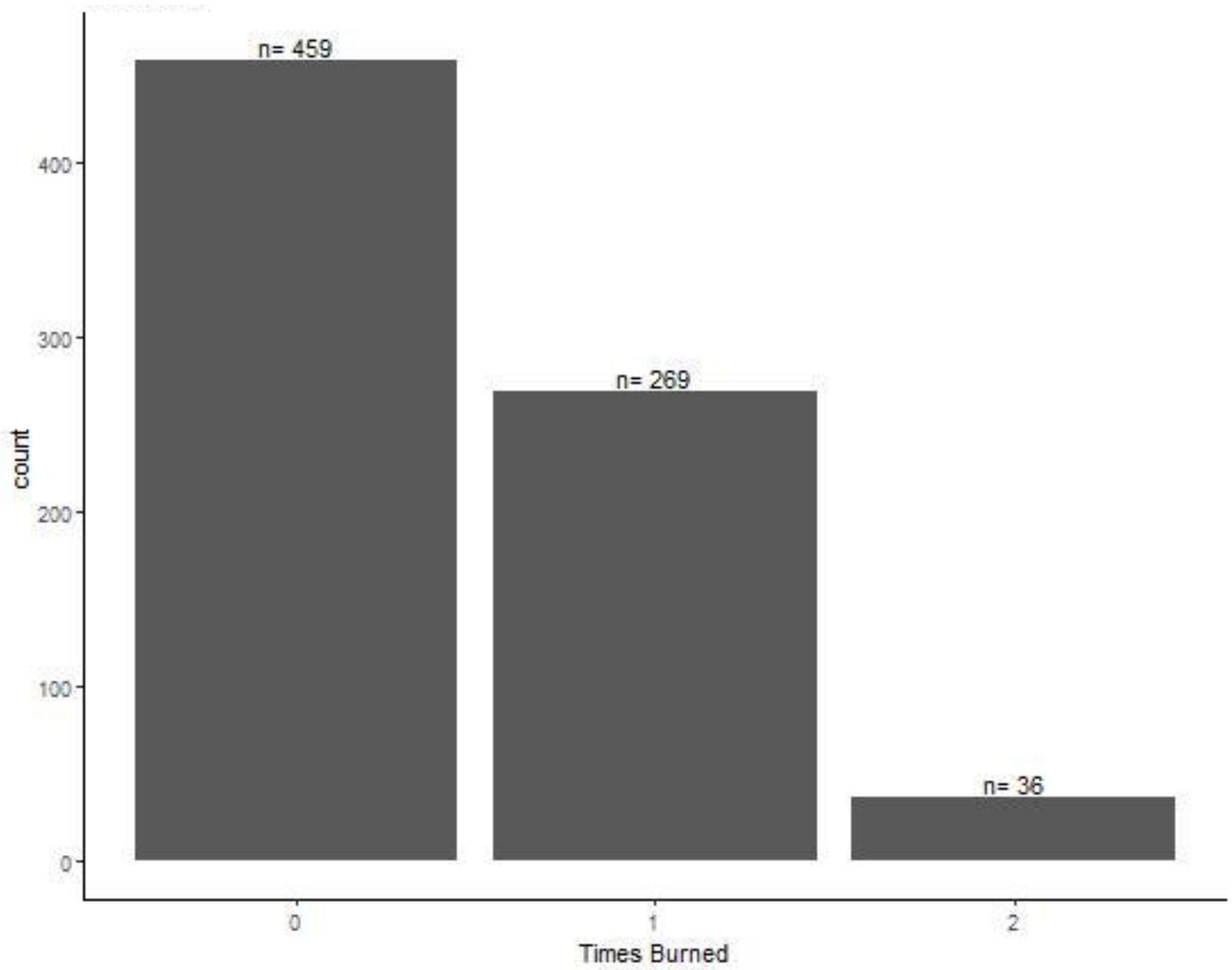

Figure 7. Histogram of plot counts with number of fires. 


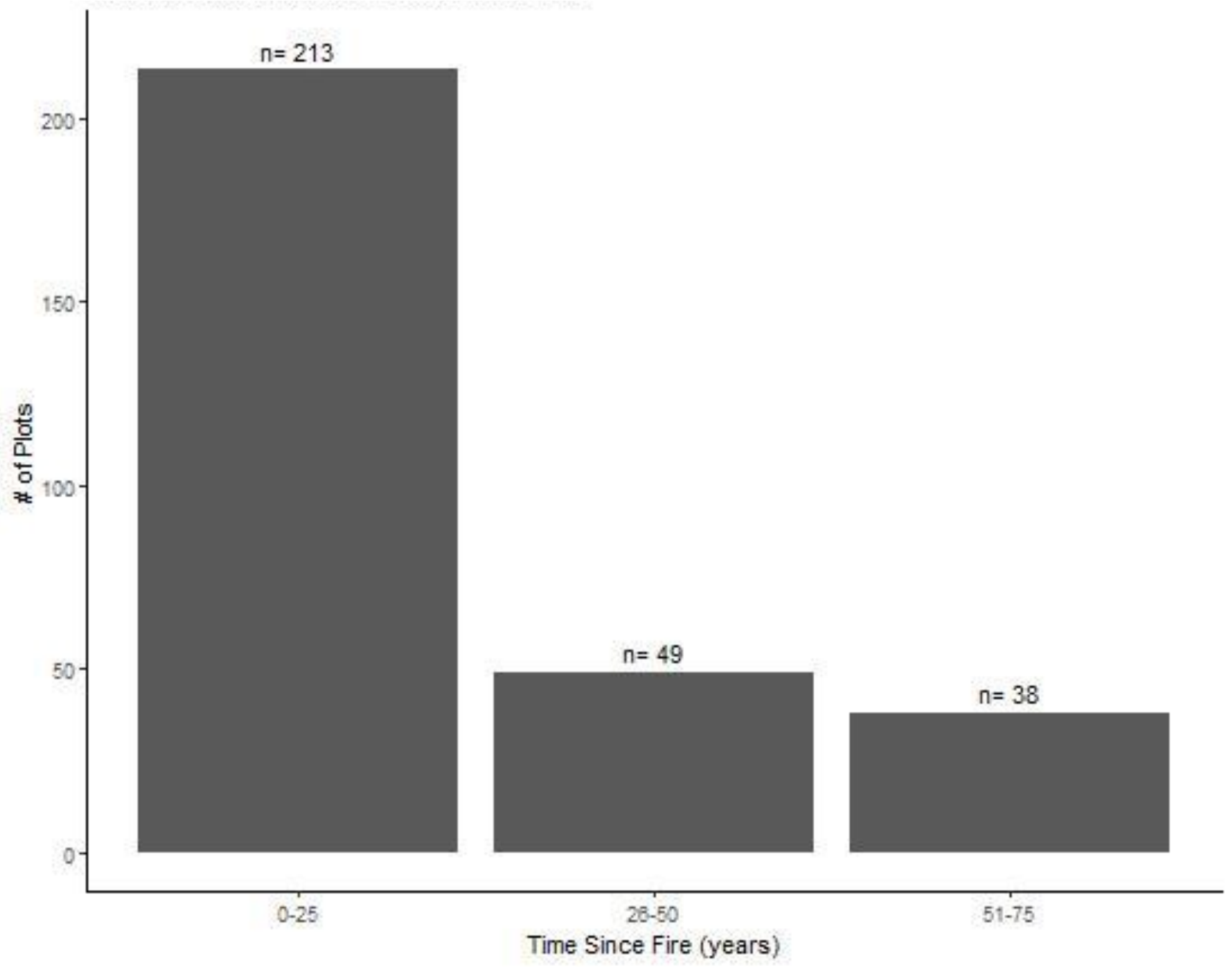

Figure 8. Histogram of plot counts with time since fire. 

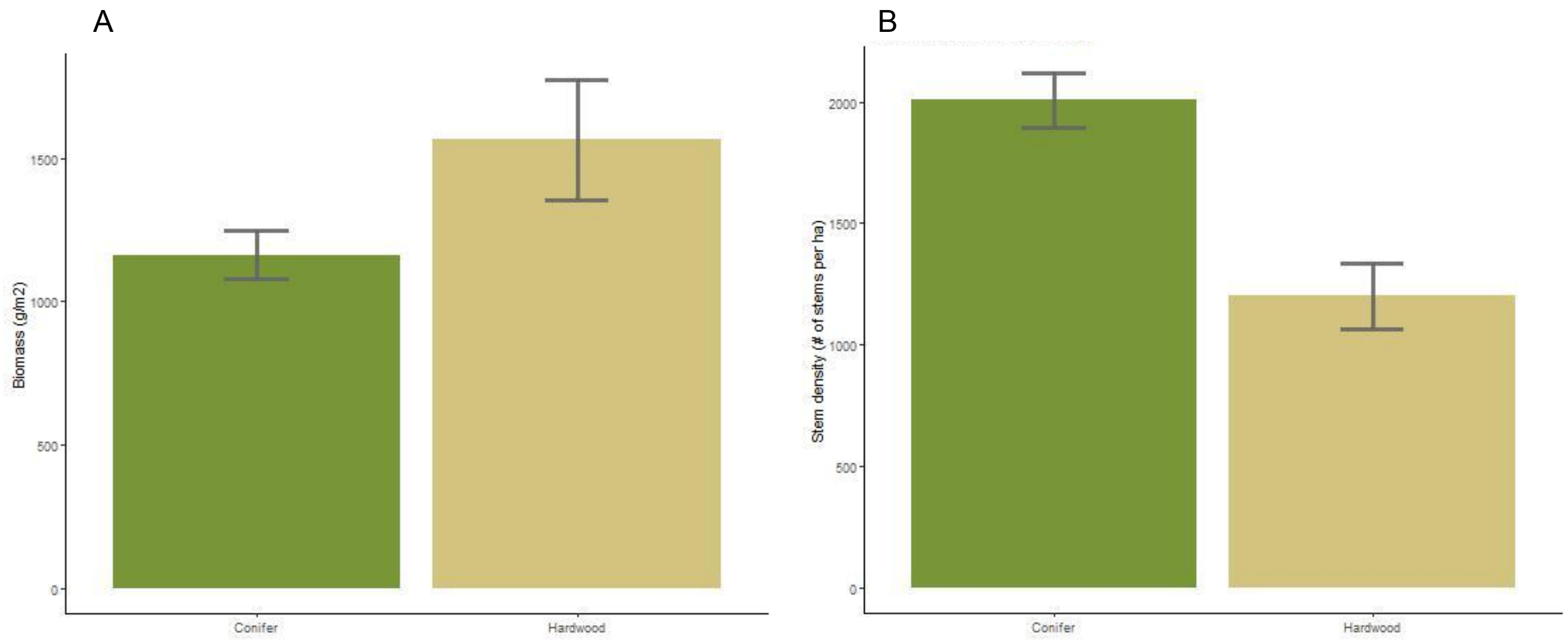

Figure 9. Forest types and (A) aboveground biomass as well as (B) stem density. 

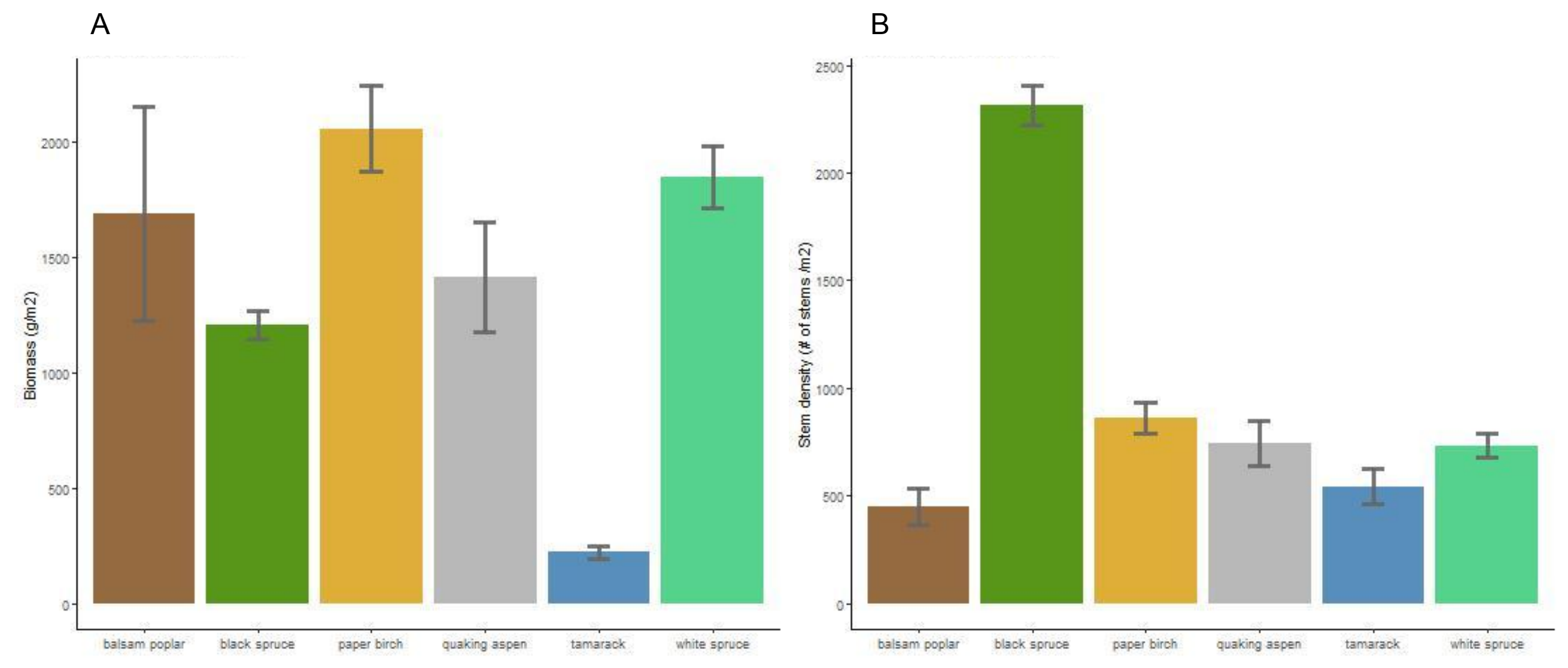

Figure 10. Tree species and (A) aboveground biomass as well as (B) stem density. 
A

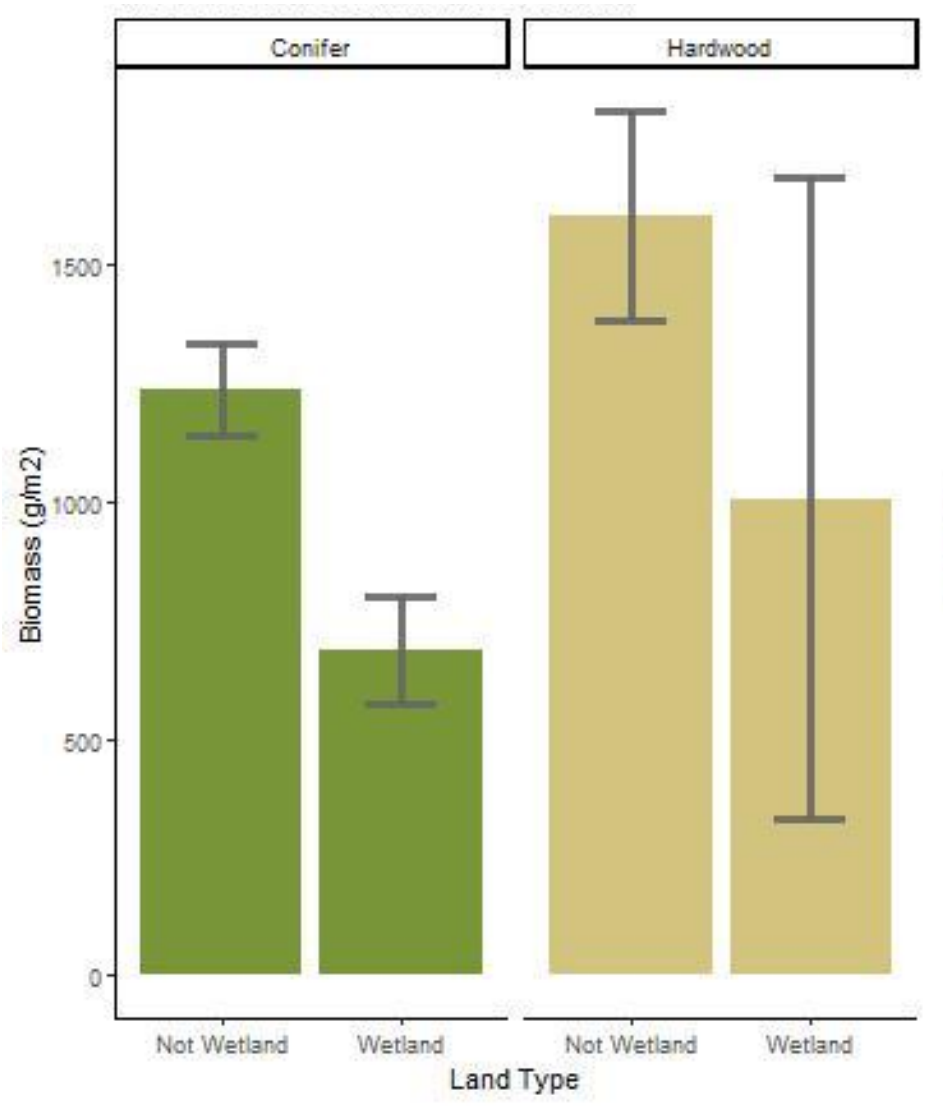

B

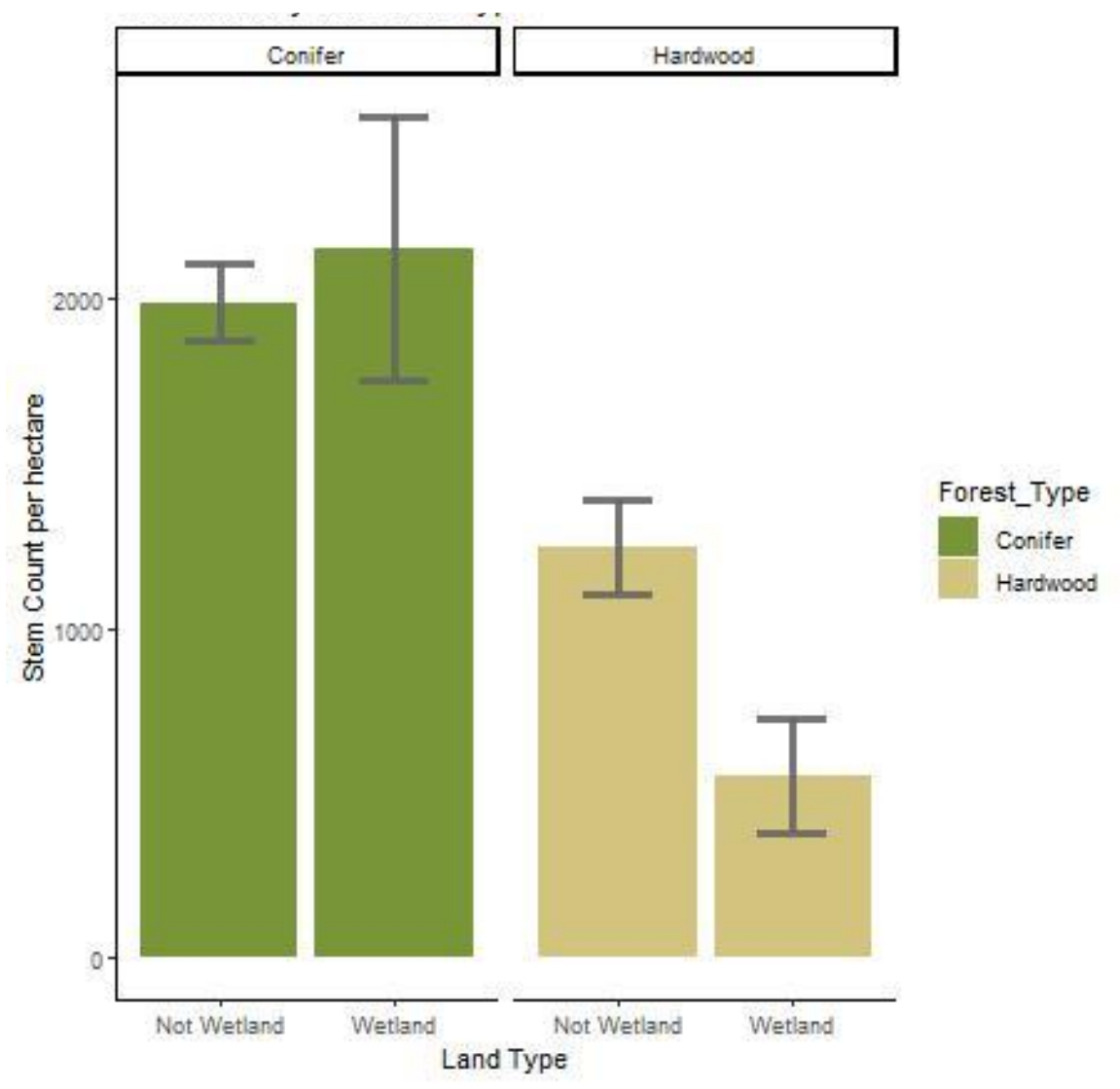

Figure 11. Comparison of conifer and hardwood aboveground biomass (A) and stem density (B) in wetlands and non-wetlands. 
A

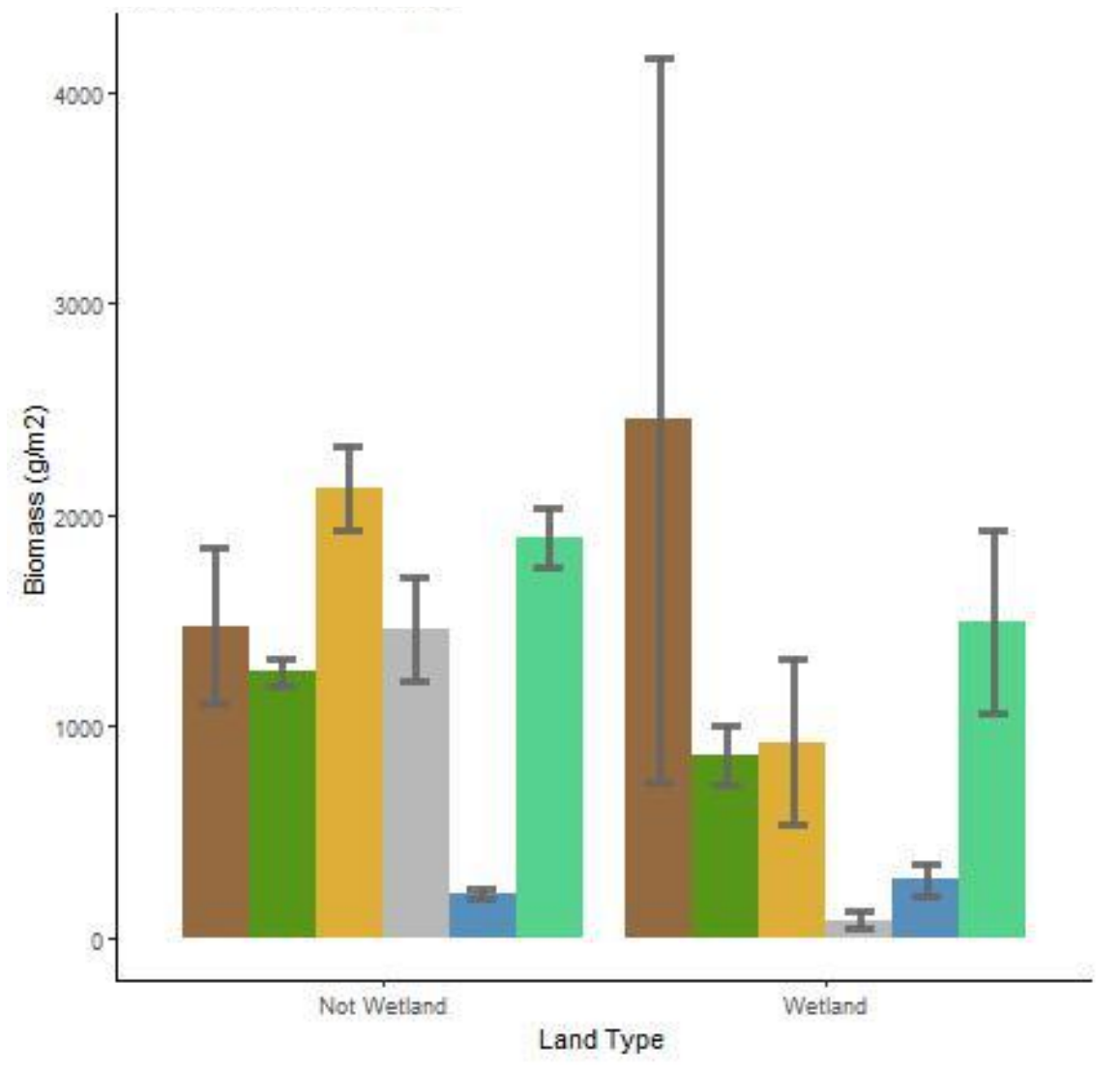

B

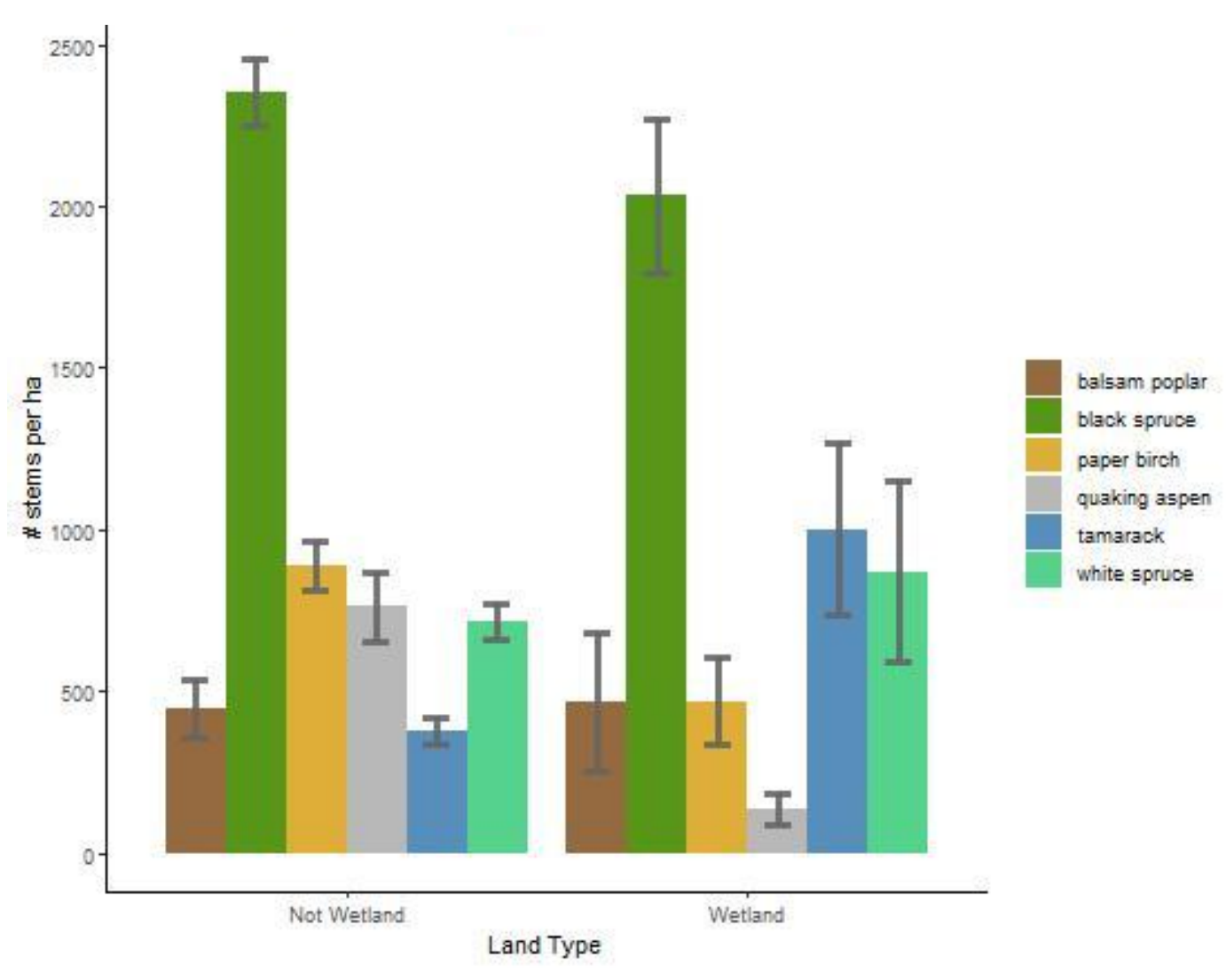

Figure 12. Comparison of species aboveground biomass (A) and stem density (B) at wetlands and non-wetlands. 

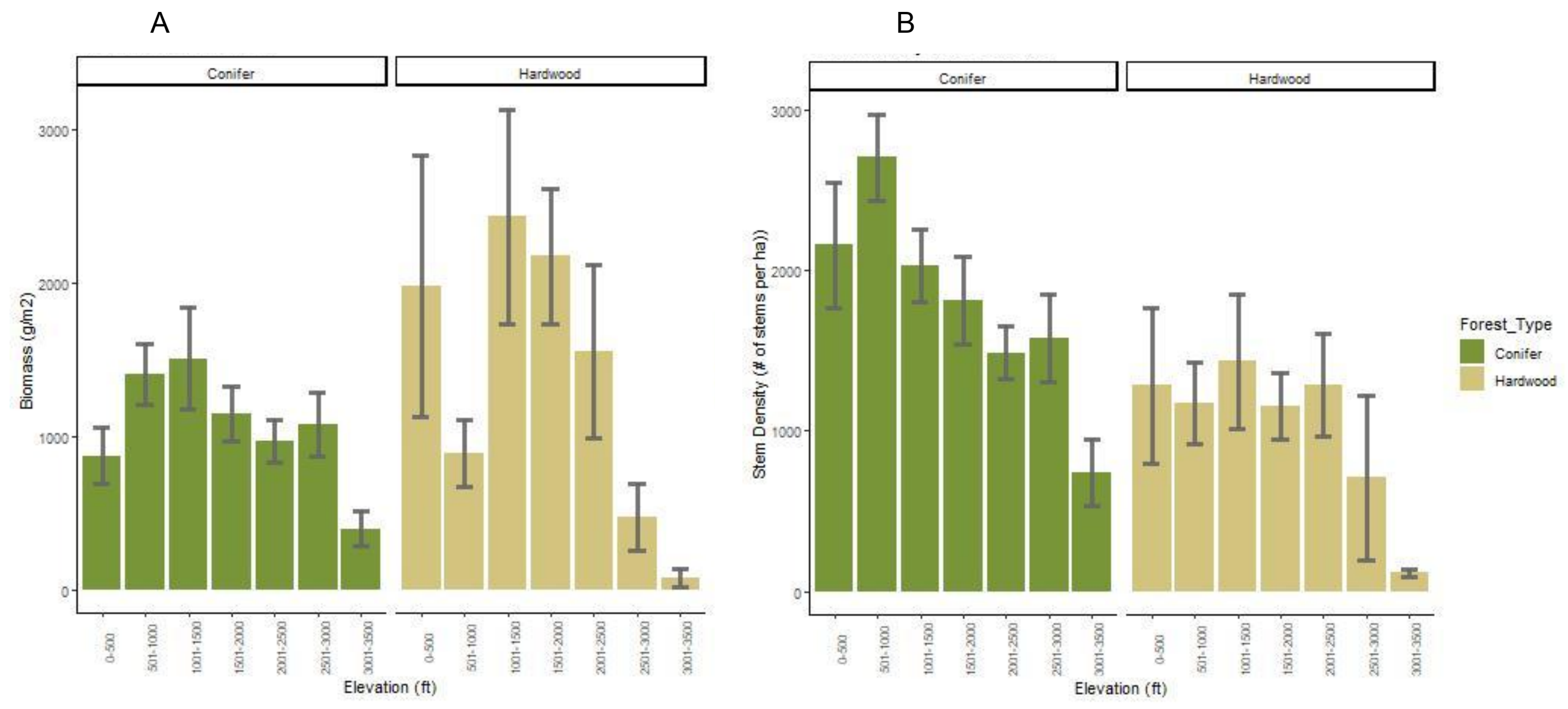

Figure 13. Comparison of conifer and hardwood aboveground biomass (A) and stem density (B) at varying elevations. 
A

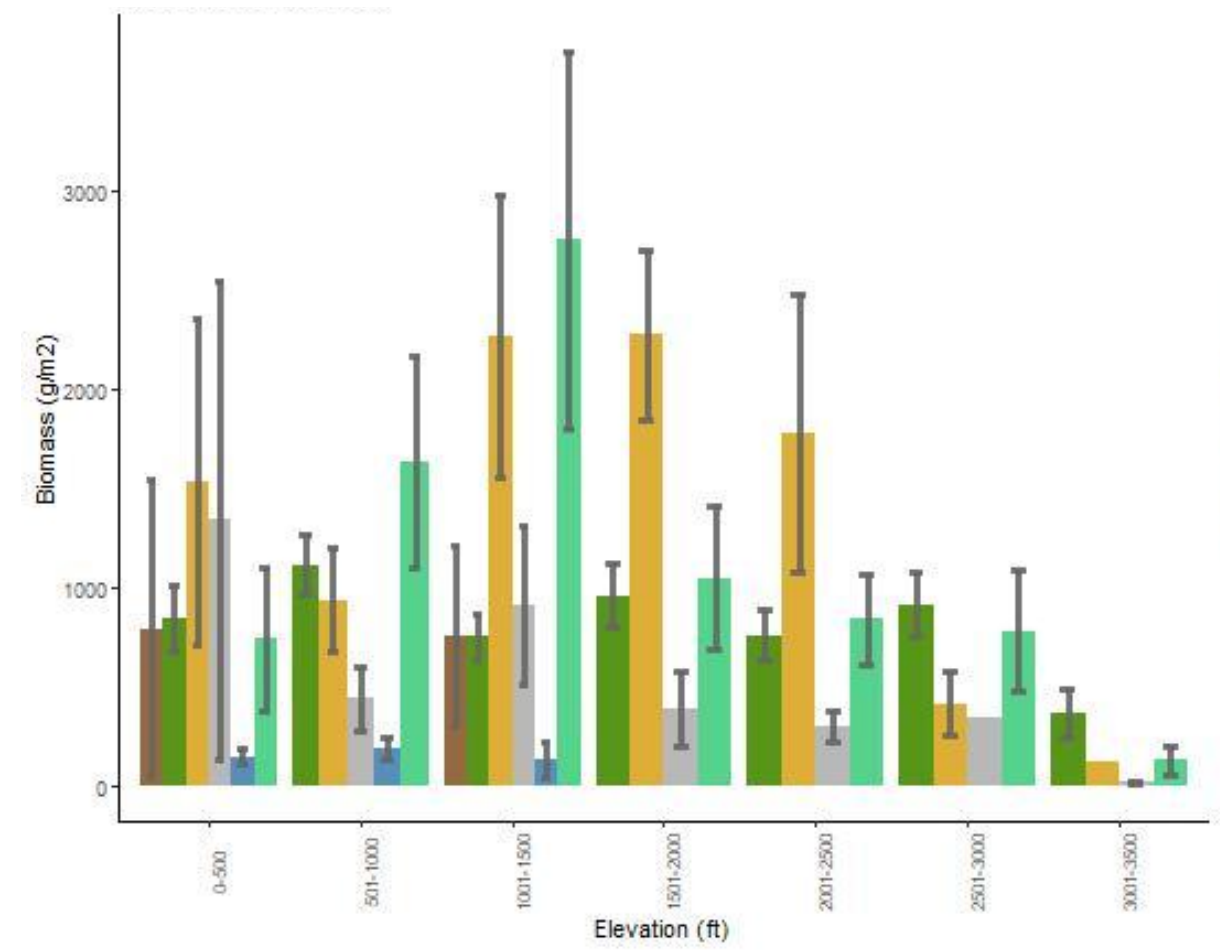

B

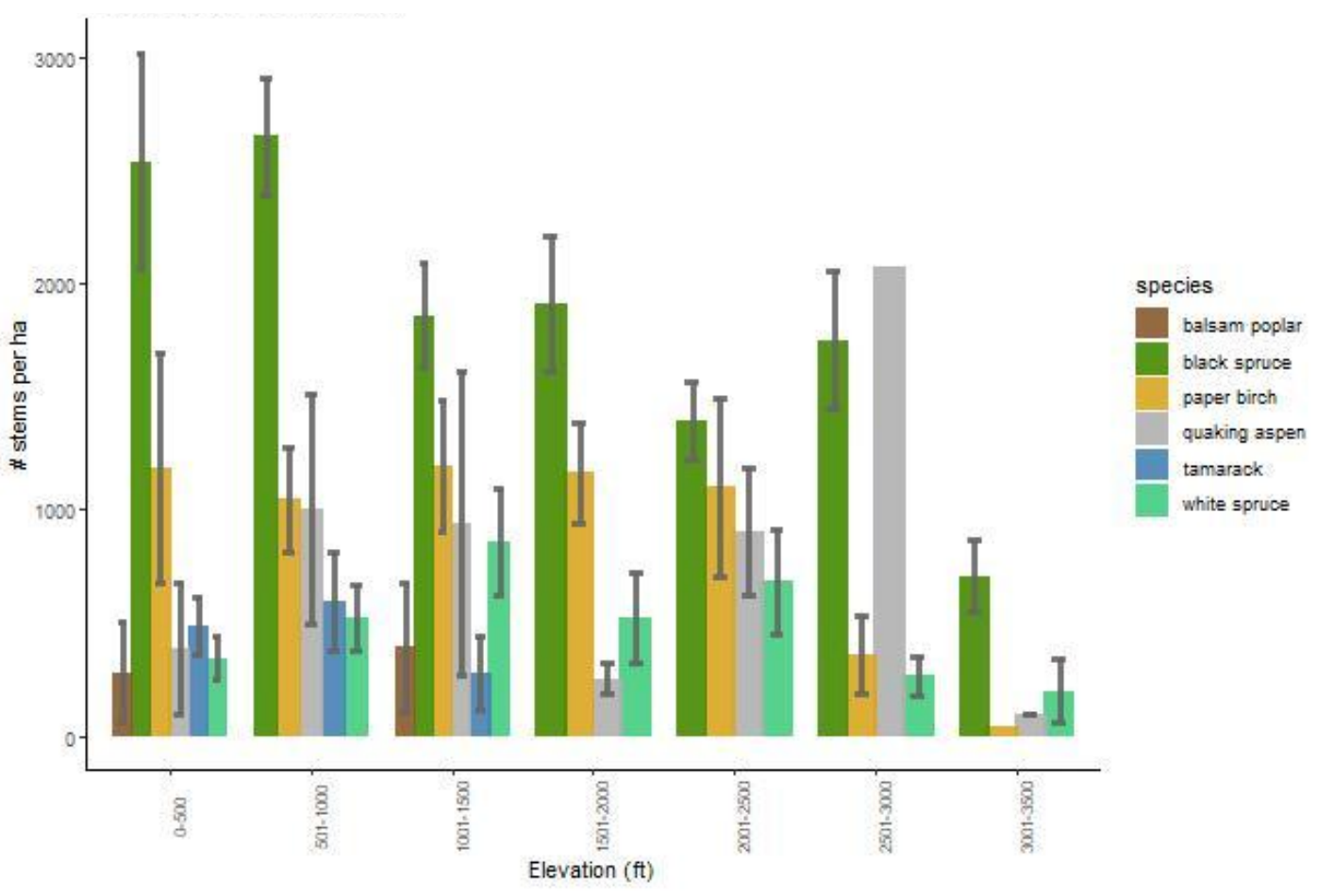

Figure 14. Comparison of species aboveground biomass (A) and stem density (B) at varying elevations. 



Figure 15. Comparison of conifer and hardwood aboveground biomass (A) and stem density (B) at varying slopes. 
A

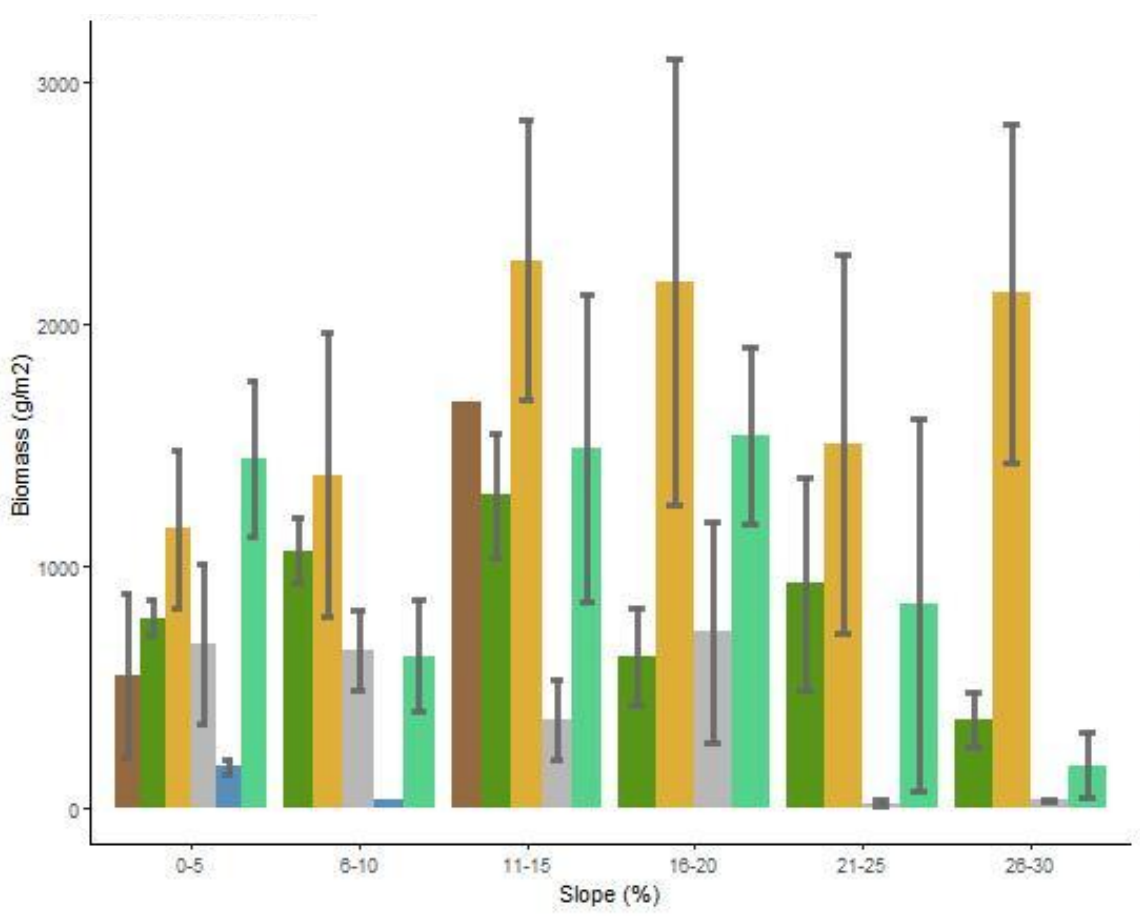

B

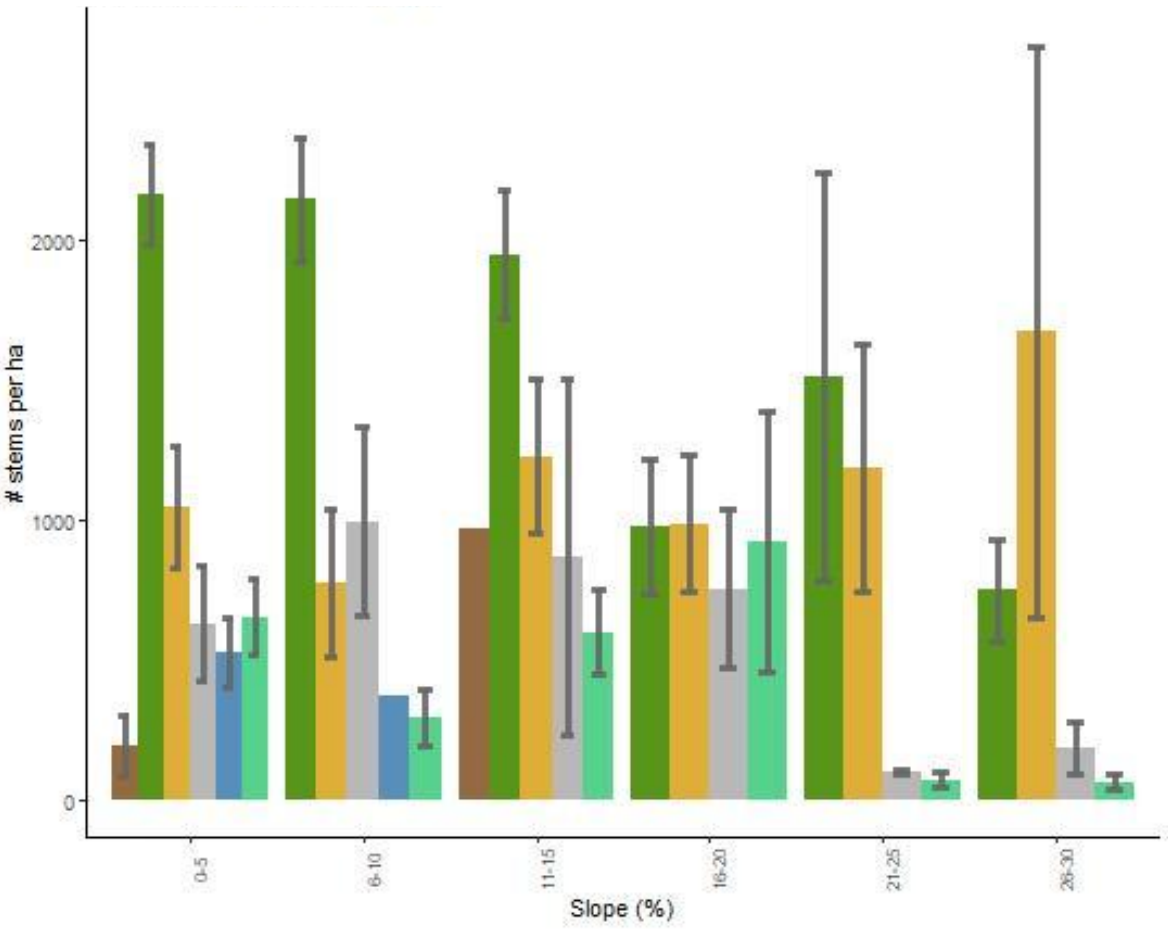

species

balsam poplar

black spruce

paper birch

quaking aspen

tamarack.

white spruce

Figure 16. Comparison of species aboveground biomass (A) and stem density (B) at varying slopes. 
A

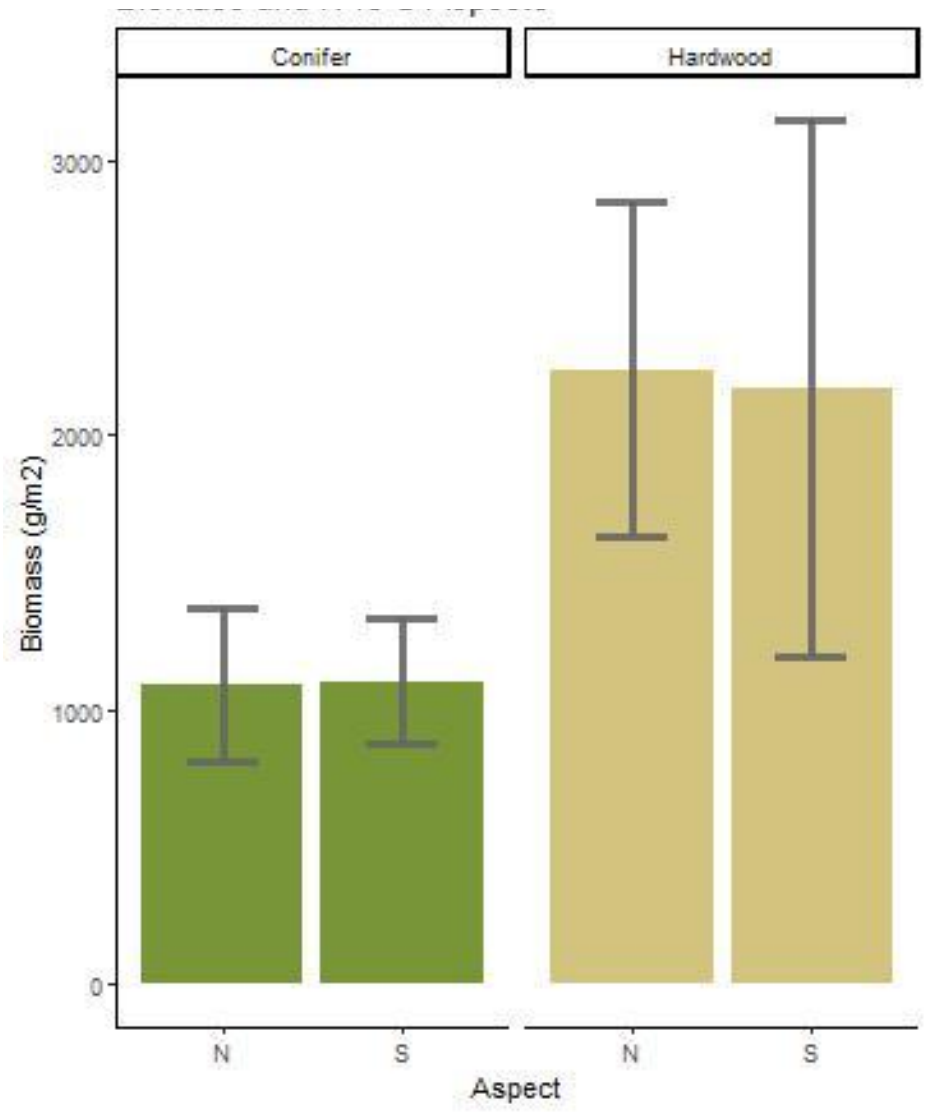

B

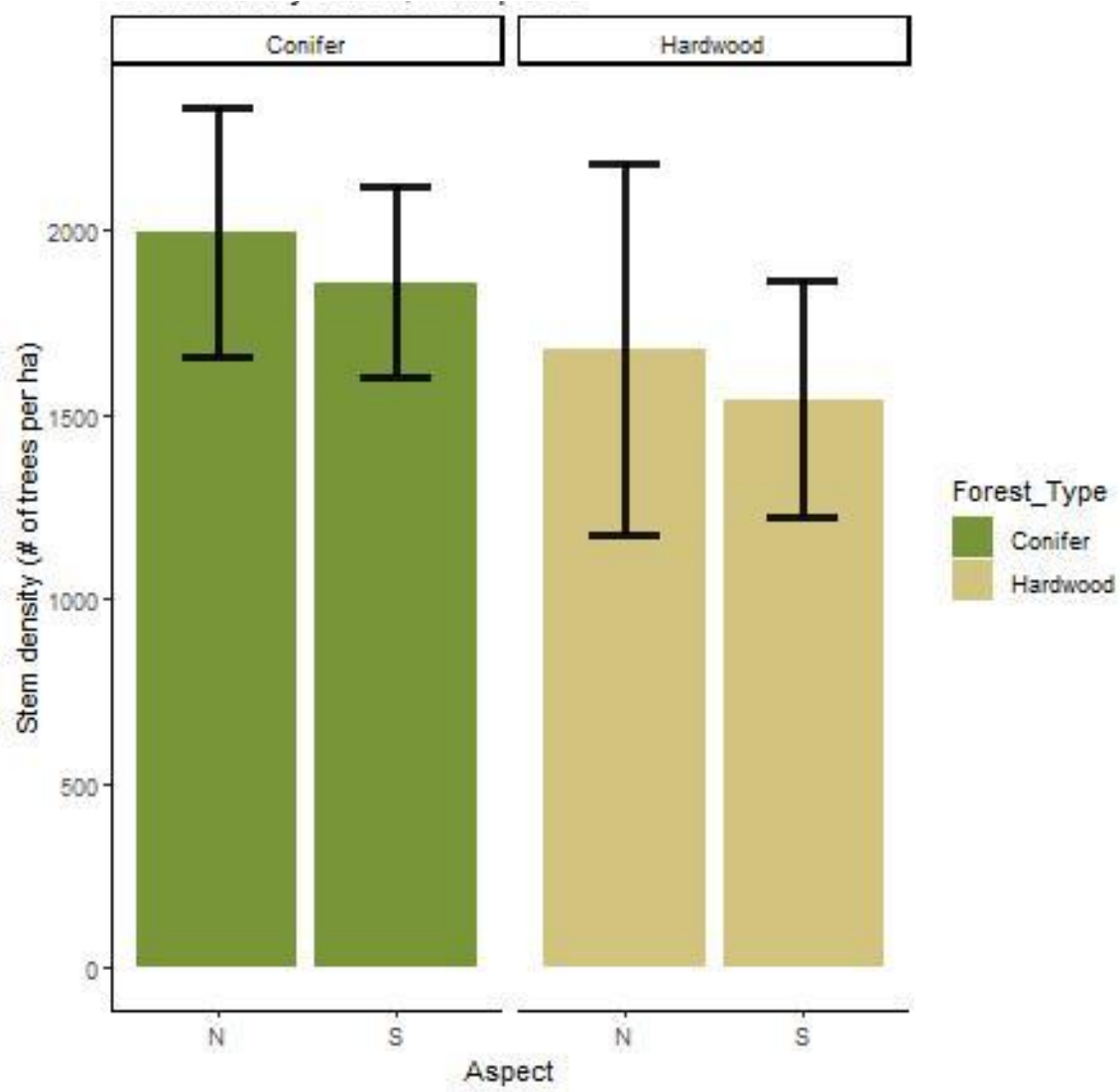

Figure 17. Comparison of conifer and hardwood aboveground biomass (A) and stem density (B) at north and south aspects. 

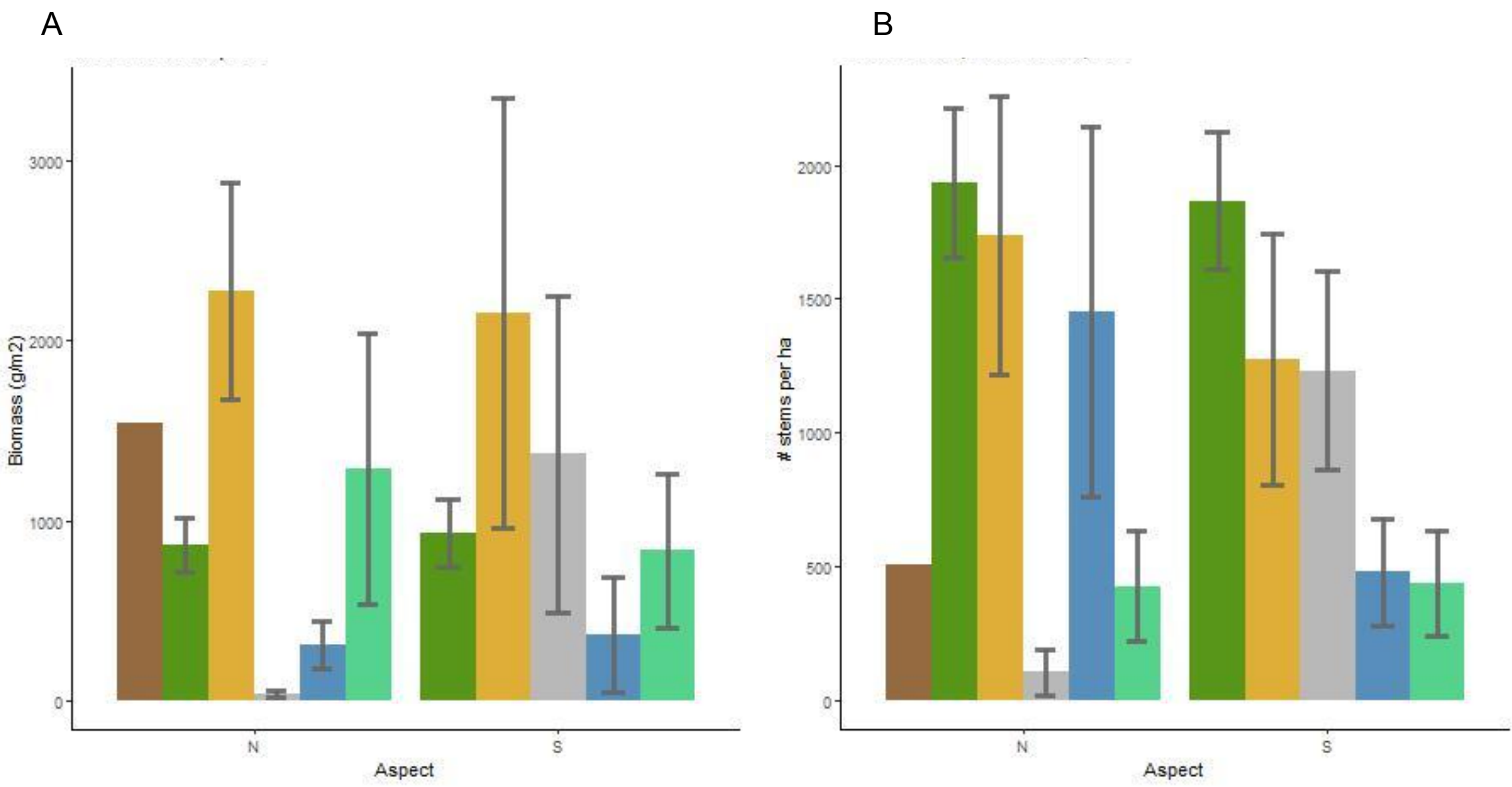

species

balsam poplar

black spruce paper birch

quaking asper tamarack

white spruce

Figure 18. Comparison of species aboveground biomass (A) and stem density (B) at north and south aspects. 

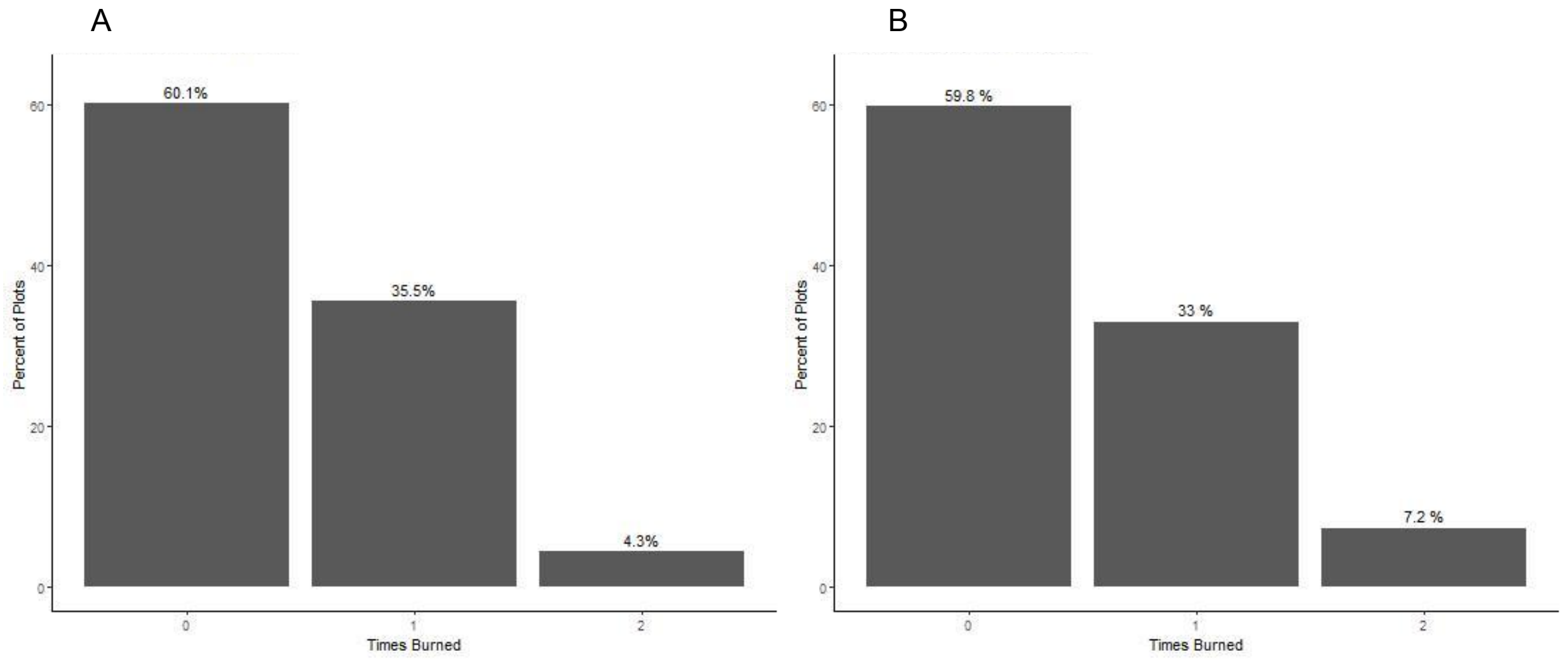

Figure 19. Percentage of plots that experiences 0,1 and 2 burns at non-wetlands (A) and wetlands (B). 
A

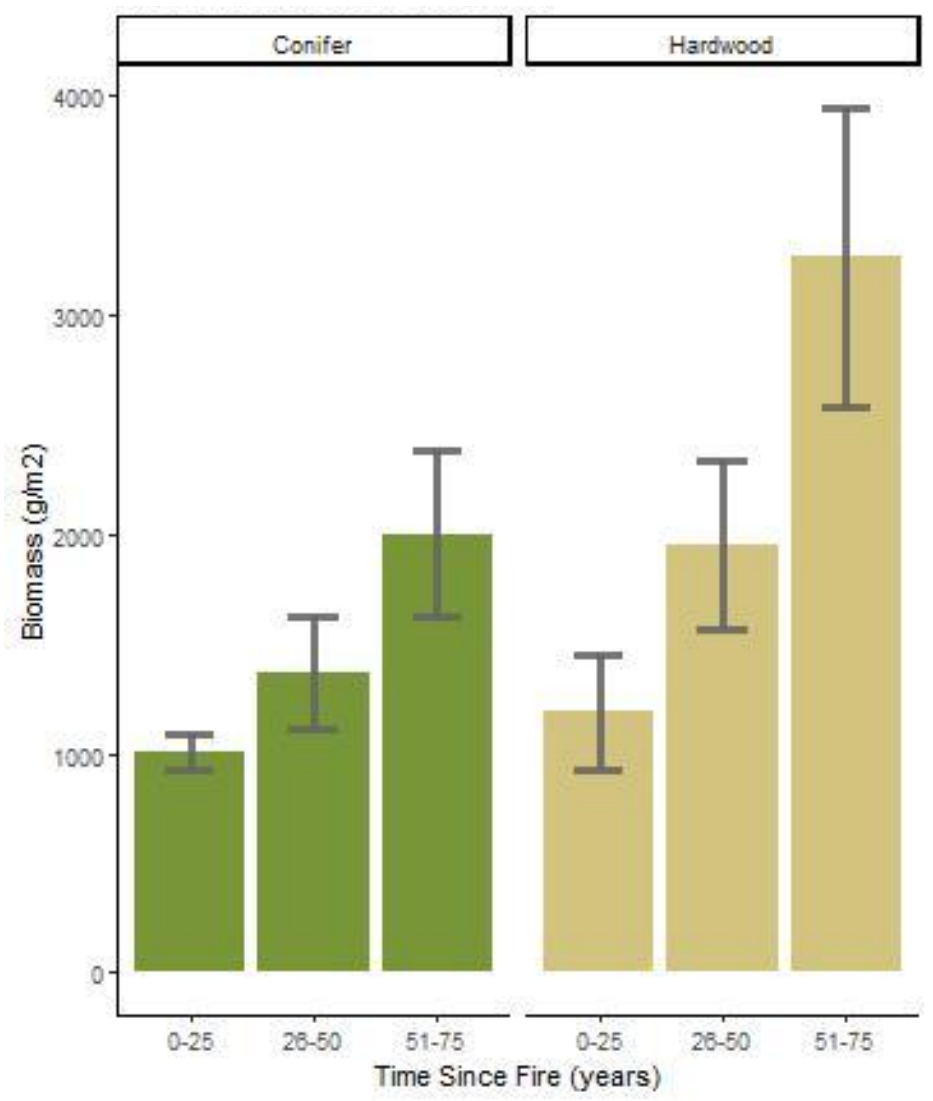

B

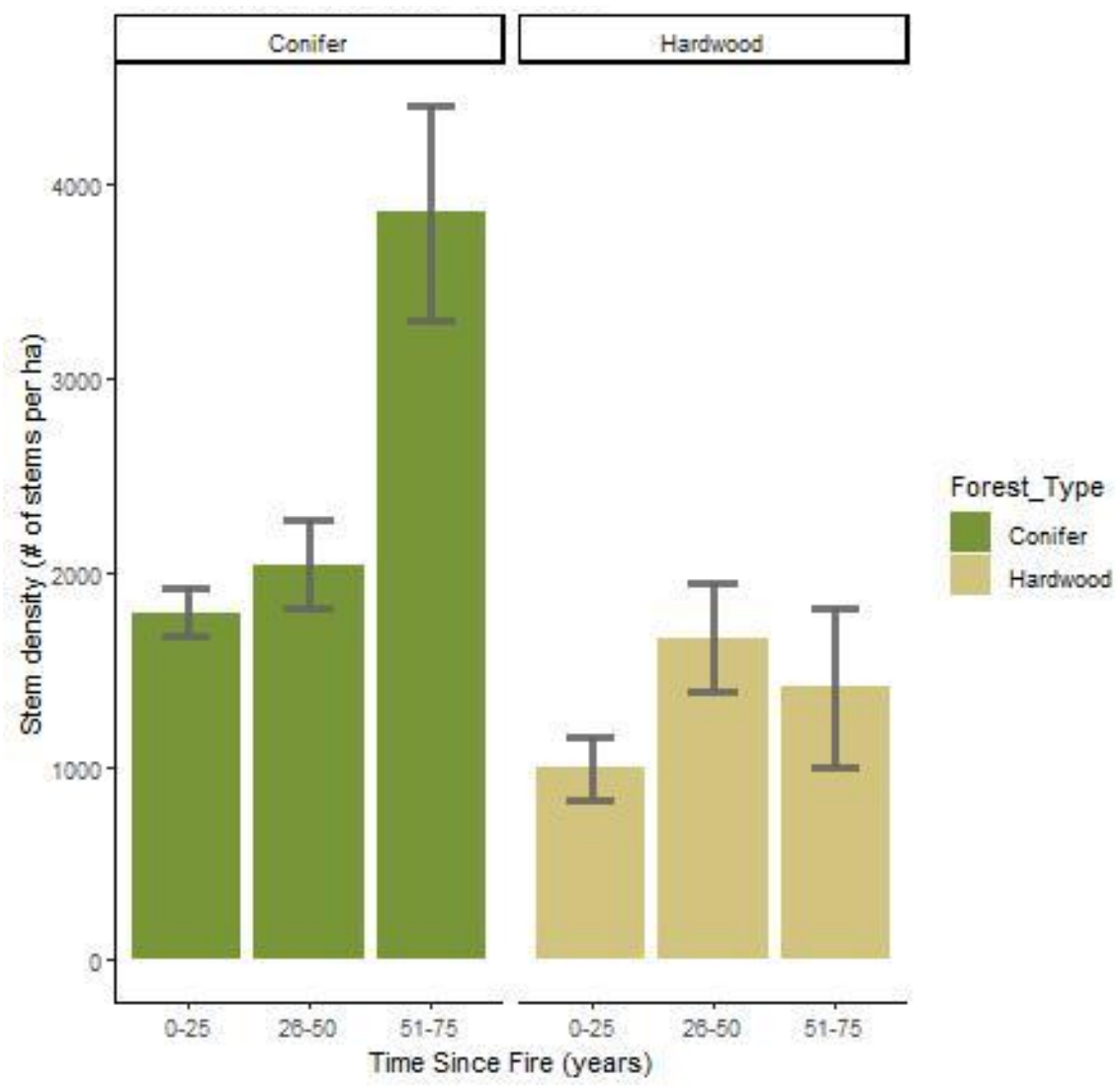

Figure 20. Comparison of conifer and hardwood aboveground biomass (A) and stem density (B) at varying times since fire. 

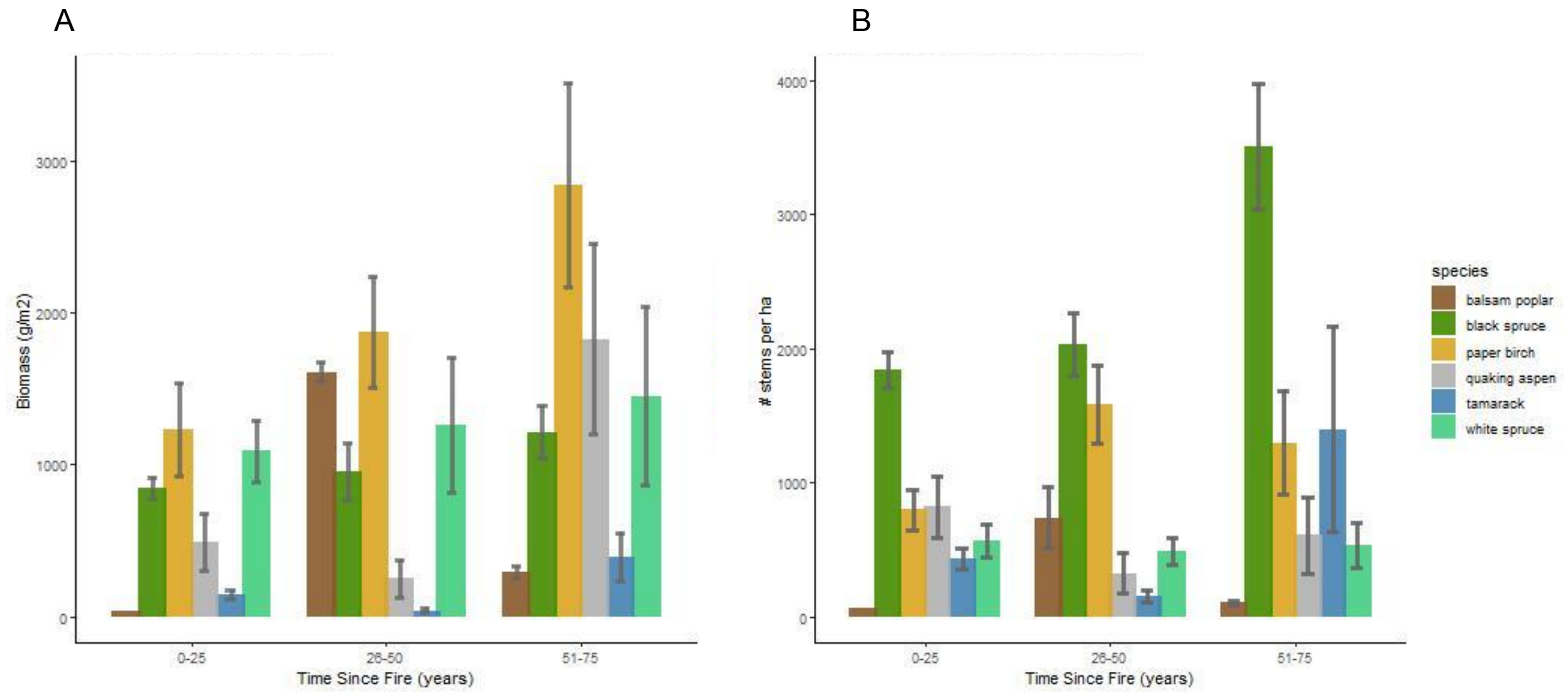

Figure 21. Comparison of species aboveground biomass (A) and stem density (B) at varying times since fire. 
A

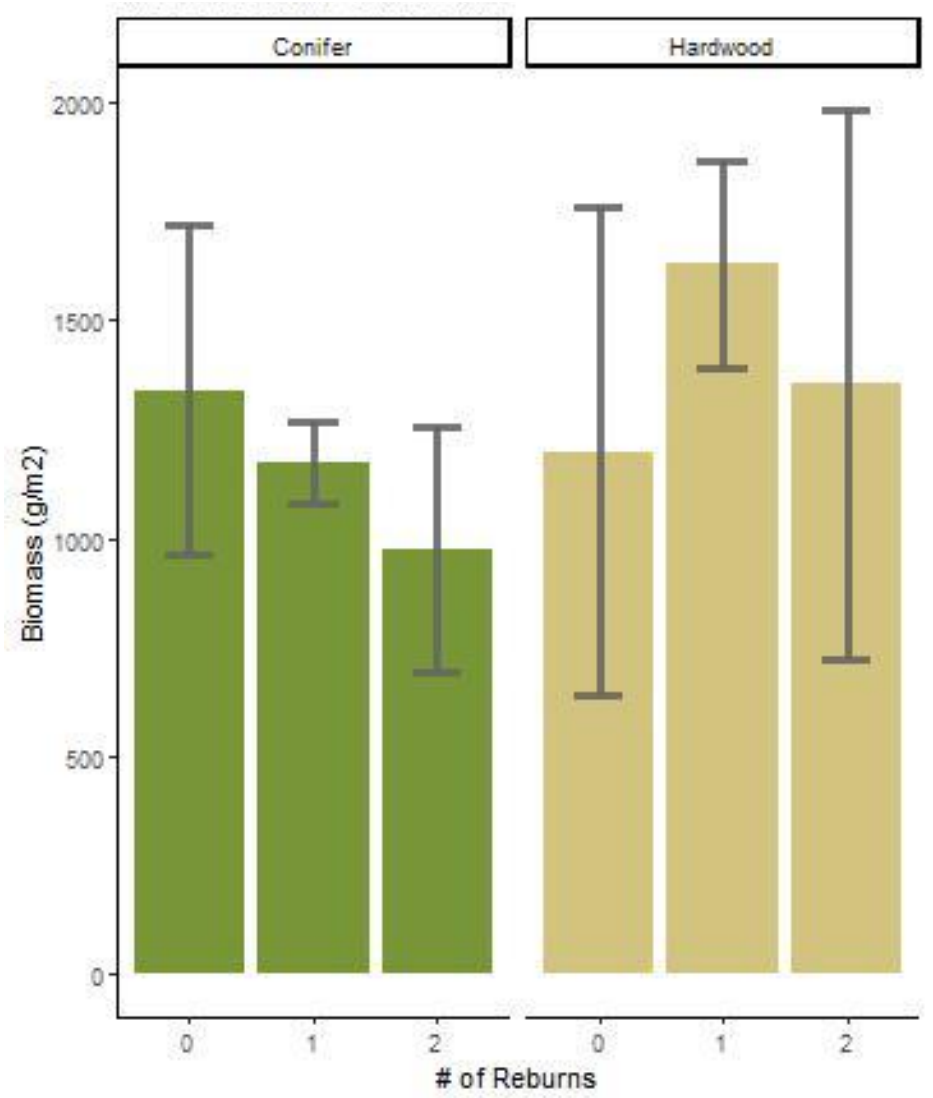

B

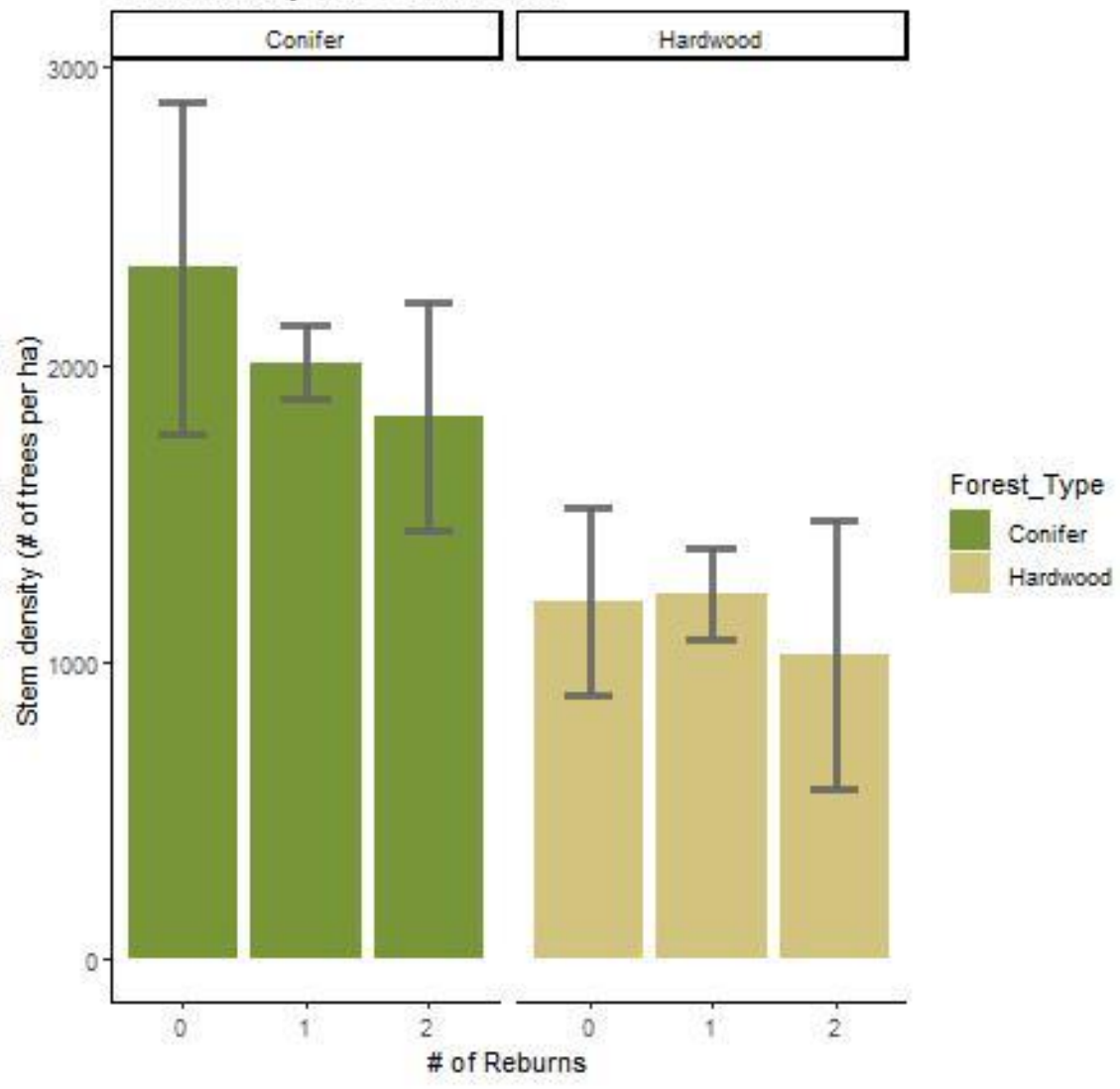

Figure 22. Comparison of conifer and hardwood aboveground biomass (A) and stem density (B) at varying number of reburns. 
A

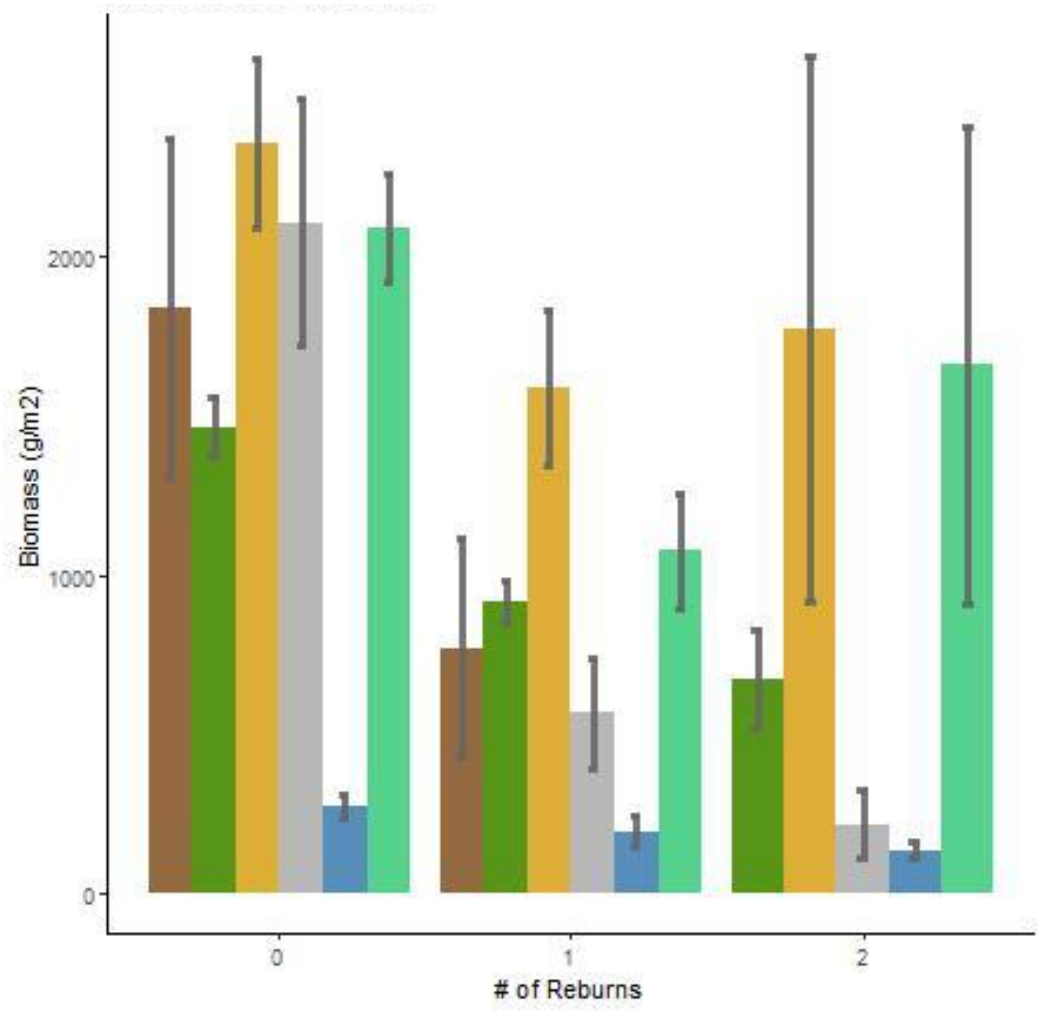

B

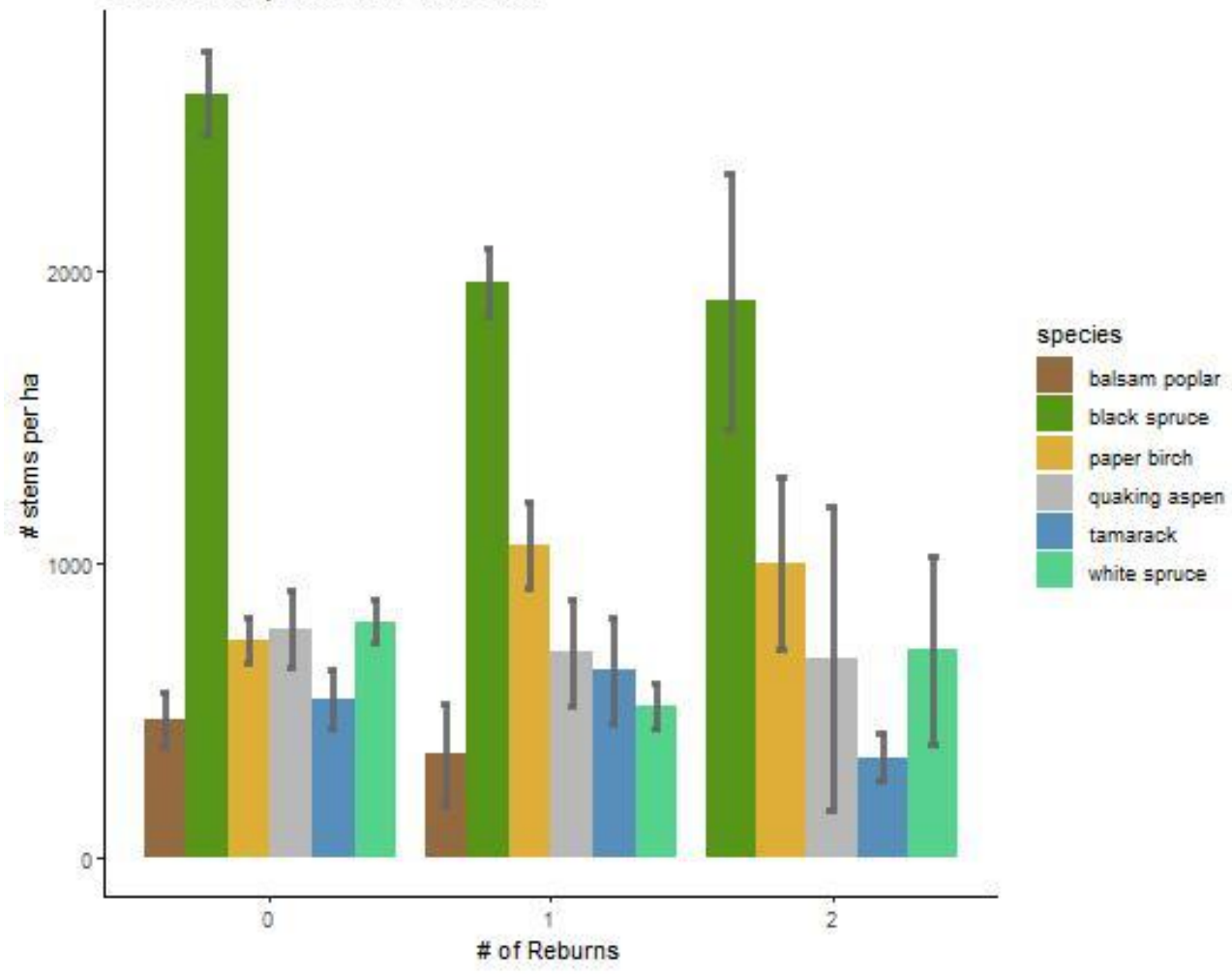

Figure 23. Comparison of species aboveground biomass (A) and stem density (B) at varying number of reburns. 